\title{
MIDDLE TRIASSIC PALEOSOLS AND PALEOCLIMATE OF ANTARCTICA
}

\author{
G.J. RETALLACK ${ }^{1}$ AND A.M. ALONSO-ZARZA ${ }^{2}$ \\ ${ }^{1}$ Department of Geological Sciences, University of Oregon, Eugene, Oregon 97403-1272, U.S.A. \\ ${ }^{2}$ Departamento de Petrología y Geoquímica, Universdidad Complutense, Madrid 28040, Spain
}

\begin{abstract}
The Lashly Formation in the Allan Hills of southern Victoria Land, Antarctica, is now at a latitude of $76^{\circ} \mathrm{S}$ and during the Middle Triassic was at least $70^{\circ} \mathrm{S}$. The combined evidence of fossil roots and soils indicates a paleoclimate unusual for such a high latitude. Temperate paleotemperature is indicated by roots, logs, and leaves of woody plants and the degree of chemical weathering and clay formation within the paleosols. Paleosols of the Lashly Formation are more like soils of southern Sweden than those of either Finland or southern Europe. Silt infiltration structures around root traces and in cracks within the paleosols are evidence for a seasonally snowy climate, but there is no evidence of ice wedges or other permafrost features in the paleosols. Other evidence of climatic seasonality includes well-defined growth rings in fossil wood, and abscission scars at the base of fossil leaves. Diverse broadleaf plants, and noncalcareous paleosols, indicate a humid climate with mean annual precipitation of about $1200 \mathrm{~mm}$. Such a wet climate is anomalous for the interior of the supercontinent of Pangea, and such a warm and mildly seasonal climate is anomalous for such high latitudes. This paleoclimatic anomaly may be a lingering effect of global greenhouse initiated at the Permian-Triassic boundary. Paleoclimatic variables calculated here may be useful for recalibrating global paleoclimatic models for the middle Triassic.
\end{abstract}

\section{INTRODUCTION}

An intriguing puzzle emerging from exploration of polar regions in the late nineteenth and early twentieth centuries was the discovery there of fossil plants now characteristic of low rather than high latitudes (Heer 1868; Seward 1914). Some of these riddles were solved by the theory of plate tectonics, but others have remained as evidence of global climate very different in the past than now. During the Middle Triassic (240 Ma), for example, Antarctica was at high latitudes (73-69: Barrett 1991; Scotese 1994; Veevers et al. 1994), yet fossil wood and leaves of forests are found in the continent now shrouded in ice (E.L. Taylor et al. 1990; E.L. Taylor et al. 1992; T.N. Taylor et al. 1990; Creber 1990). Fossil plants of such geological antiquity have only distant relatives in modern vegetation (T.N. Taylor et al. 1993) and preferentially preserve lowland peat-forming vegetation adapted to local waterlogging rather than regional climate (E.L. Taylor et al. 1989). Fossil vertebrates including large labyrinthodonts also can be argued as evidence for a nearly frost-free climate (Hammer 1990; Hammer et al. 1990) by analogy with living alligators (Markwick 1994), but the physiology of these extinct creatures remains controversial (Bakker 1986). In contrast, computer models give extreme paleoclimate in northern Victoria Land during the Middle Triassic: mean annual temperature of $-5^{\circ} \mathrm{C}$, and annual range of temperature of $55^{\circ} \mathrm{C}$ from $-30^{\circ} \mathrm{C}$ in winter to $25^{\circ} \mathrm{C}$ in summer (Kutzbach 1994). Here we use paleosols, now known to be abundant in Triassic rocks of Antarctica (Pyne 1984; Gabites 1985; Barrett and Fitzgerald 1986; Woolfe et al. 1996; Retallack et al. 1997a, 1997b), as evidence for paleoclimate during deposition of the lower Lashly Formation of southern Victoria Land, Antarctica.

\section{GEOLOGICAL SETTING}

The Beacon Supergroup in southern Victoria Land is an undeformed backarc sequence (Collinson 1990; Collinson et al. 1994). In the Allan Hills (Fig. 1) the exposed sequence is entirely nonmarine and includes the Permian Weller Coal Measures, overlain by the Early Triassic Feather Con- glomerate (here largely sandstone) and the Middle Triassic Lashly Formation (Fig. 2; Ballance 1977; Woolfe et al. 1996). Our observations are from the lower Lashly Formation (Members A and B), which is more volcaniclastic than the quartzose upper part of the formation (Members C and D; Collinson et al. 1983; Korsch 1984).

The age of Members A and B of the Lashly Formation in the Allan Hills has been determined as Middle Triassic (late Anisian to Ladinian) based on fossil plants of the Dicroidium odontopteroides zone of Retallack (1977c, 1978), an age confirmed by subsequent collections (Gabites 1985; E.L. Taylor et al. 1990; T.N. Taylor et al. 1990). Even the base of Member A of the Lashly Formation is Middle Triassic, as indicated by the following fossil plants collected from $200 \mathrm{~m}$ west of our measured section (at $258 \mathrm{~m}$ in Figure 2): Dicroidium crassinervis forma stelznerianum, Dicroidium coriaceum, Umkomasia sp., and Neocalamites carrerei (Condon Collection University of Oregon, nos. F35106-10). Recent high-precision dating of the D. odontopteroides zone indicates that it began at $243 \mathrm{Ma}$ (Retallack et al. 1993) and ended at about $230 \mathrm{Ma}$ (Veevers 1989; Veevers et al. 1994).

Pollen and spores have not yet been reported from the Allan Hills, but Members A and B of the Lashly Formation elsewhere in Victoria Land have yielded assemblages of subzones A and B of the Late Early to early Middle Triassic (late Scythian to Anisian) Alisporites zone (of Kyle 1977; Kyle and Schopf 1982). The upper part of the Lashly Formation (Members $\mathrm{C}$ and D) has yielded subzones $\mathrm{C}$ and D of the Alisporites zone of Late Triassic age (Kyle 1977; Kyle and Schopf 1982).

No Triassic fossil vertebrates have been found in the Allan Hills, despite several deliberate searches (Hammer and Zawiskie 1982; Chatterjee et al. 1983), but the Fremouw Formation in the central Transantarctic Mountains contains a fauna at levels with paleosols similar to those of the lower Lashly Formation in Victoria Land. The fauna has some genera of the Cynognathus zone of South Africa, but includes more advanced forms and so is late Early to early Middle Triassic (late Scythian to Anisian) in age (Hammer 1990; Hammer et al. 1990).

The Lashly Formation has pronounced upward-fining fluvial cycles: basal trough cross-bedded sandstones grading up through flaggy siltstones and sandstones into green-gray mudstones with abundant root traces. These claystones have been interpreted as flood-plain deposits and the sandstones as channel deposits of braided streams draining northwards (Collinson et al. 1994; Zwartz and Woolfe 1996; Woolfe et al. 1996).

\section{MATERIALS AND METHODS}

A stratigraphic section was measured in the central Allan Hills (Figs. 1, 2; $76^{\circ} 42.2^{\prime} \mathrm{S}, 159^{\circ} 44.4^{\prime} \mathrm{E}$ ). Fossil plants were also collected (Condon Collection nos. F35100-10). Each paleosol type, or pedotype (in the sense of Retallack 1994) was characterized in detail (Tables 1-4), including observations on Munsell color and reaction with dilute acid (following Retallack 1988). Because of the local shortage of place names, each pedotype is named after Antarctic researchers (Retallack et al. 1997a). The type example and some other examples of the pedotypes were sampled for chemical and petrographic analysis, including point-counting 500 points in thin section for grain size (Table 5) and mineral composition (Table 6) using a Swift point-counter (by AAZ), with accuracy of about 2\% (Murphy 1983). Full chemical analysis was by ICP and XRF, with $\mathrm{FeO}$ by titration and loss on ignition at $1000^{\circ} \mathrm{C}$ (Tables 7-8). 


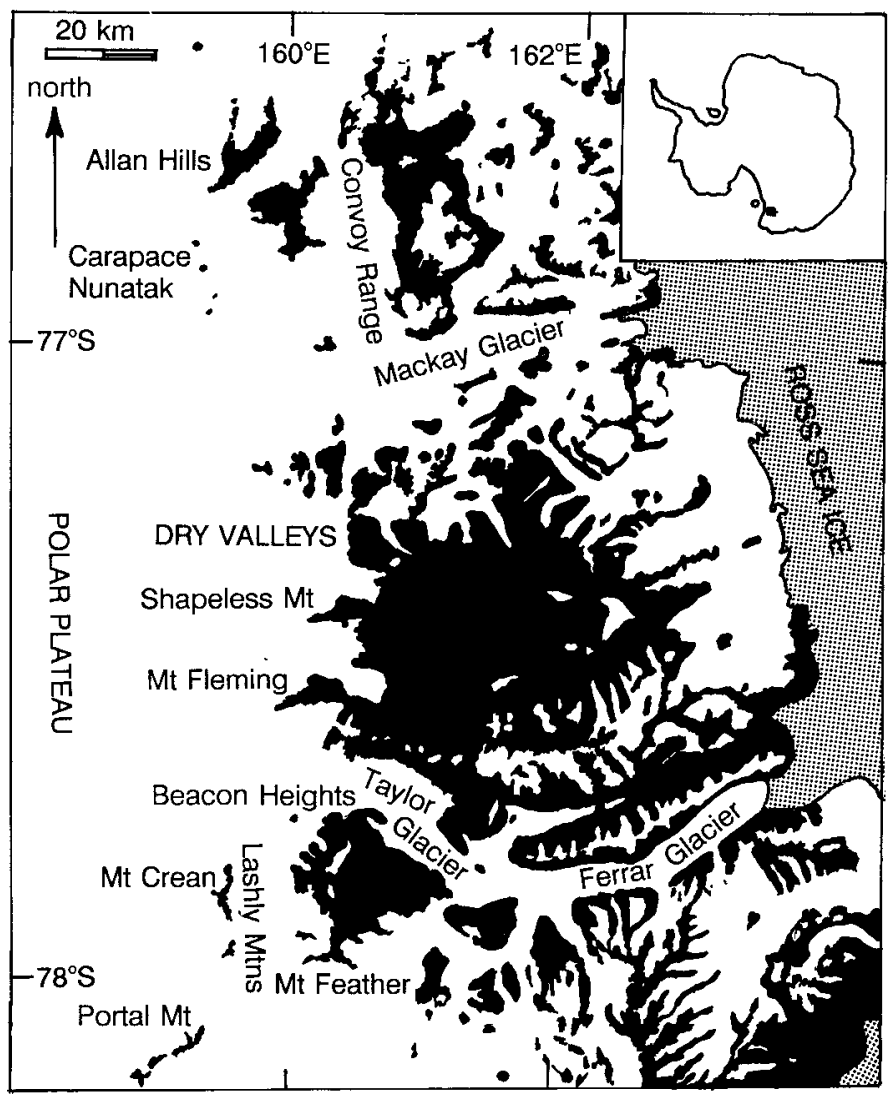

FIG. 1.-Rock and soil (black), and location of Allan Hills in southern Victoria Land, Antarctica.

\section{FOSSIL ROOT TRACES}

\section{Field Observations}

Carbonaceous root traces are found in some of the fossil plant localities, particularly those with fossil horsetails (258 $\mathrm{m}$ in Figure 2). The rhizomes and adventitious roots of the horsetails form planar mats, more or less concordant with strata. Such root mats are common in waterlogged soils, where root penetration is prevented by stagnant groundwater (Jenik 1978).

More abundant are deeply penetrating and copiously branching white root traces in greenish-gray claystones (Fig. 3). These are widespread in the Lashly Formation within southern Victoria Land (Gabites 1985), from Portal Peak north to the Allan Hills (Retallack et al. 1997a). Identical root traces and paleosols also are common in the Middle Triassic upper Fremouw Formation of the Beardmore Glacier region of the central Transantarctic Mountains (Horner and Krissek 1991; Retallack et al. 1997b).

These distinctive white root traces range in size from 1 to $12 \mathrm{~mm}$ in diameter, with the fine rootlets branching from stout, nearly vertical tap roots. Thick (up to $8 \mathrm{~mm}$ diameter) subhorizontal roots with lateral rootlets also were seen (Gabites 1985). Individual root systems emanate downward from bedding planes interpreted as the tops of paleosols, and could be traced for vertical distances of some $50 \mathrm{~cm}$. No trace of the original carbonaceous material of the white root traces can be found. The clay-size mineral filling these root traces is banded concentrically in colors of white and light gray, and is unreactive to acid.

\section{Petrographic and Mineral Composition of White Root Traces}

Our XRD traces, EDAX microprobe analyses, and petrographic examination of the white root traces show that the main filling material is white

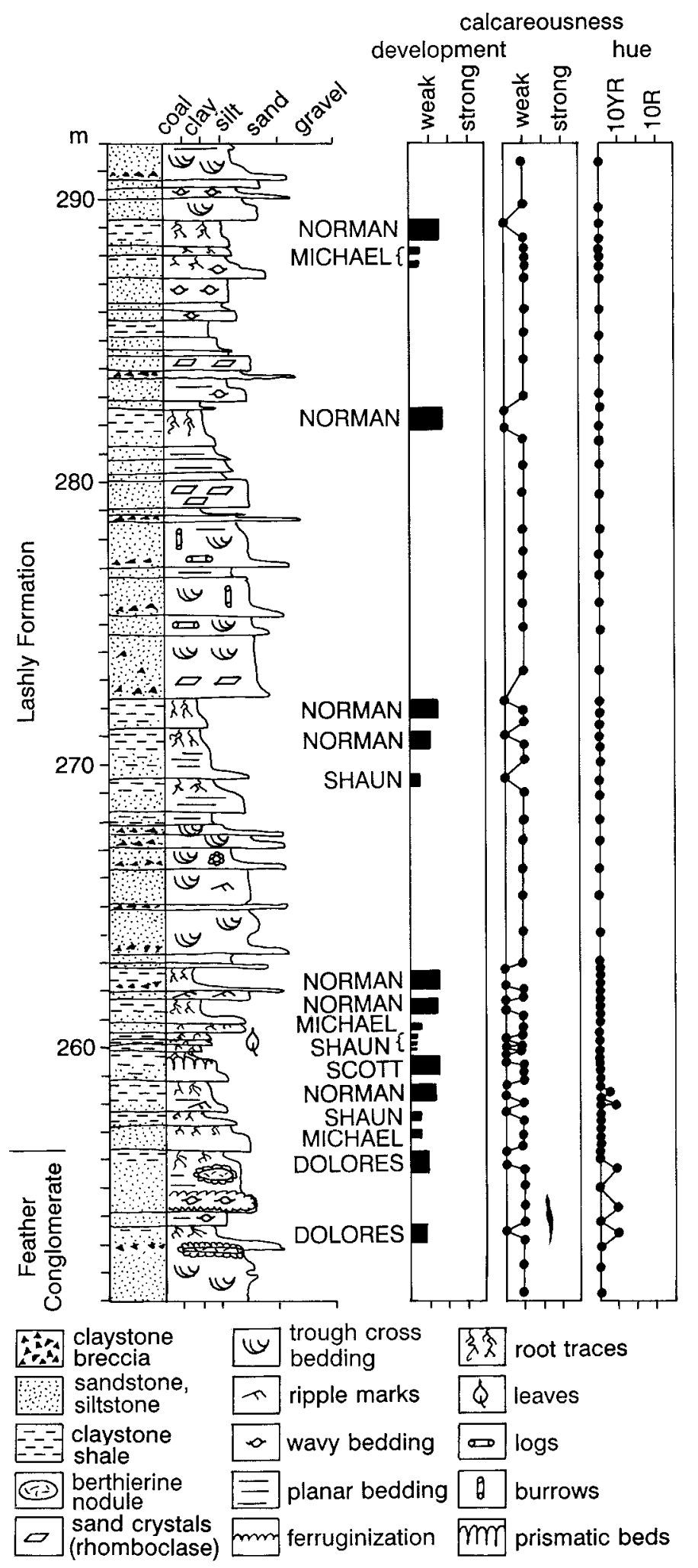

FIG. 2.-A measured section of paleosols in the upper Feather Conglomerate and lower Lashly Formation in the central Allan Hills, Antarctica $\left(76^{\circ} 42.2^{\prime} \mathrm{S}, 159^{\circ}\right.$ $44.4^{\prime} \mathrm{E}$ ). Meter levels are from a longer measured section here (Retallack et al. 1997a). Hue is from a Munsell color chart, and reaction with acid for calcareousness and degree of development are from scales of Retallack (1988). Names of paleosols are pedotypes (of Retallack 1994). 
TABLE 1.-Description of the type Michael paleosol.

\begin{tabular}{|c|c|c|c|c|c|c|}
\hline $\begin{array}{l}\text { Depth } \\
(\mathrm{cm})\end{array}$ & $\mathrm{Hz}$ & Rock & Color & Other Features & Micromorphology & Contact \\
\hline$+17 \mathrm{~cm}$ & $\mathrm{C}$ & $\begin{array}{c}\text { Fine-grained } \\
\text { sandstone }\end{array}$ & $\begin{array}{l}\text { Light olive } \\
\text { gray (5Y6/ } \\
2 \text { ) }\end{array}$ & $\begin{array}{l}\text { Common relict bed- } \\
\text { ding; medium } \\
\text { mottles olive } \\
\text { gray }(5 Y 5 / 2) ; \\
\text { distinct medium } \\
\text { nodules dark yel- } \\
\text { lowish brown } \\
\text { (10YR4/4); } \\
\text { weakly calcare- } \\
\text { ous }\end{array}$ & $\begin{array}{l}\text { Intertextic mosepic } \\
\text { to skelsepic com- } \\
\text { mon redeposited } \\
\text { soil clasts, some } \\
\text { quartz, feldspar, } \\
\text { mica and } \\
\text { opaques }\end{array}$ & $\begin{array}{l}\text { Abrupt } \\
\text { smooth to }\end{array}$ \\
\hline $0 \mathrm{~cm}$ & $\mathrm{~A}$ & $\begin{array}{c}\text { Fine-grained } \\
\text { sandstone }\end{array}$ & $\begin{array}{r}\text { Light gray } \\
(5 Y 7 / 2)\end{array}$ & $\begin{array}{l}\text { Common white } \\
\text { (5Y8/1) root trac- } \\
\text { es up to } 13 \mathrm{~mm} \\
\text { in diameter; in- } \\
\text { distinct relict } \\
\text { bedding; weakly } \\
\text { calcareous }\end{array}$ & $\begin{array}{l}\text { Intertextic mosepic } \\
\text { to skelsepic; } \\
\text { common quartz, } \\
\text { few soil clasts } \\
\text { and rock frag- } \\
\text { ments; some } \\
\text { feldspar, mica } \\
\text { and opaques }\end{array}$ & $\begin{array}{l}\text { Gradual } \\
\text { smooth to }\end{array}$ \\
\hline$-13 \mathrm{~cm}$ & $\mathrm{C}$ & $\begin{array}{c}\text { Fine-grained } \\
\text { sandstone }\end{array}$ & $\begin{array}{r}\text { Light gray } \\
(5 Y 7 / 1)\end{array}$ & $\begin{array}{l}\text { Prominent relict } \\
\text { bedding; sparse } \\
\text { copiously branch- } \\
\text { ing fine white } \\
\text { (5Y8/1) root trac- } \\
\text { es; few narrow } \\
\text { (3-4 mm } \\
\text { diameter) bur- } \\
\text { rows filled with } \\
\text { olive gray (5Y4/ } \\
\text { 2) claystone }\end{array}$ & $\begin{array}{l}\text { Intertextic skelse- } \\
\text { pic; common } \\
\text { quartz and soil } \\
\text { fragments, some } \\
\text { rock fragments, } \\
\text { feldspar and } \\
\text { opaques }\end{array}$ & $\begin{array}{l}\text { Abrupt } \\
\text { smooth to }\end{array}$ \\
\hline
\end{tabular}

chalcedony and light gray illite, mixed-layer illite-smectite, and rare kaolinite (Figs. 4-8). Chemical composition of these clays is similar to that of the surrounding paleosol matrix. In some cases the concentric laminae within the root traces include silt and larger grains of the surrounding soil. Concentric interlamination of clay and chalcedony is common, as seen by microprobe mapping and traverses (Figs. 5-6). Degraded fibers of chalcedony were found in the root traces (Fig. 4A). The chalcedony is length slow and so could be called quartzine. Other crystalline structures proved to be sanidine (Fig. 4C) and orthoclase (Fig. 4D) in volcanic rock fragments. We looked hard for zeolites and carbonate in petrographic thin sections, EDAX analyses or XRD traces, but found none. These white root traces were not calcareous rhizoconcretions like those of soils in dry climates (for comparison see Retallack 1991a).

\section{Origin of the White Root Traces}

The lack of organic matter and deep penetration of the white root traces are evidence of well drained soils. In well aerated soils, root penetration and decomposition of organic matter are unhindered. The first phase in the formation of these white root traces would have been rotting out of the buried root traces, followed by filling with clay and silica. Some of the concentric fills could have been initiated before burial of the soil, when soil clasts and silt-size mineral grains fell down into a widening crack between the rotting root and its matrix. Most of the fill was probably formed during burial of the paleosol, because so many of them are free of sediment that fell into associated insect burrows (Gabites 1985). The time of filling was very early during burial because the white root traces fill fully inflated root holes, which have been little deformed by subsequent burial compaction. Carbonaceous root traces in the Lashly Formation are deformed by burial compaction into a concertina-like shape. In contrast, the white root traces are like permineralized logs in the Lashly Formation in resistance to burial compaction.

The source of silica filling the root traces is unlikely to be illitization or pressure solution because neither of these effects of deep burial are marked in the Lashly Formation. The $10 \AA$ peak of illite in XRD traces of the paleosols is broad and low (Fig. 7; Weaver index 0.3-0.9, Kubler index 1.2-2.4; Weber index 422-800), more like that of soils than deeply buried
TABLE 2.-Description of the type Norman paleosol.

\begin{tabular}{|c|c|c|c|c|c|c|}
\hline $\begin{array}{l}\text { Depth } \\
\text { (cm) }\end{array}$ & $\mathrm{Hz}$ & Rock & Color & Other Features & Micromorphology & Contact \\
\hline$+8 \mathrm{~cm}$ & - & $\begin{array}{l}\text { Medium- } \\
\text { grained } \\
\text { sandstone }\end{array}$ & $\begin{array}{r}\text { Light gray } \\
(5 Y 7 / 1)\end{array}$ & $\begin{array}{l}\text { Ripple marks, com- } \\
\text { plex weathering } \\
\text { rind (quasiferran) } \\
\text { brown }(10 \mathrm{YR} 4 / 3) \\
\text { inside outer stain } \\
\text { pale yellow } \\
\text { (2.5Y7/3); grains } \\
\text { gray }(5 \mathrm{Y} 5 / 1) ; \\
\text { weakly calcare- } \\
\text { ous }\end{array}$ & $\begin{array}{l}\text { Intertextic granular- } \\
\text { skelsepic; com- } \\
\text { mon volcanic } \\
\text { and metamorphic } \\
\text { rock fragments }\end{array}$ & $\begin{array}{l}\text { Abrupt, } \\
\text { smooth to } \\
\text { wavy to }\end{array}$ \\
\hline $0 \mathrm{~cm}$ & A & $\begin{array}{l}\text { Clayey silt- } \\
\text { stone }\end{array}$ & $\begin{array}{l}\text { Gray (5Y6/ } \\
\text { 1) }\end{array}$ & $\begin{array}{l}\text { Common large ( } 8 \\
\text { mm diameter) } \\
\text { white (5Y8/1) } \\
\text { root traces; slick- } \\
\text { ensided clay } \\
\text { skins (argillans) } \\
\text { light olive gray } \\
\text { (5Y6/2), outlin- } \\
\text { ing coarse-medi- } \\
\text { um subangular } \\
\text { blocky peds; ir- } \\
\text { regular medium } \\
\text { mottles gray } \\
\text { (5Y5/1); non-cal- } \\
\text { careous }\end{array}$ & $\begin{array}{l}\text { Porphyroskelic mo- } \\
\text { sepic; chalcedony } \\
\text { infill of roots; } \\
\text { mainly clay with } \\
\text { rare quartz, mica } \\
\text { and opaques. }\end{array}$ & $\begin{array}{l}\text { Gradual } \\
\text { smooth } \\
\text { contact to }\end{array}$ \\
\hline$-14 \mathrm{~cm}$ & $\mathrm{Bw}$ & Silty claystone & $\begin{array}{l}\text { Gray }(5 \mathrm{Y} 5 / \\
1)\end{array}$ & $\begin{array}{l}\text { Common white } \\
\text { (5Y8/1) root trac- } \\
\text { es; coarse angu- } \\
\text { lar blocky peds } \\
\text { outlined by clay } \\
\text { skins (argillans) } \\
\text { of olive gray } \\
\text { (5Y5/2); complex } \\
\text { weathering rind } \\
\text { (quasiferran) dark } \\
\text { yellowish brown } \\
\text { (10YR4/4) within } \\
\text { outer rind of pale } \\
\text { olive (5Y6/3); } \\
\text { non-calcareous }\end{array}$ & $\begin{array}{l}\text { Porphyroskelic mo- } \\
\text { sepic; with stri- } \\
\text { otubules and } \\
\text { laminated clay } \\
\text { skins; mainly } \\
\text { clay with rare } \\
\text { quartz, mica and } \\
\text { opaques }\end{array}$ & $\begin{array}{l}\text { Gradual } \\
\text { smooth to }\end{array}$ \\
\hline$-49 \mathrm{~cm}$ & $\mathrm{C}$ & $\begin{array}{c}\text { Fine-grained } \\
\text { sandstone }\end{array}$ & $\begin{array}{l}\text { Light olive } \\
\text { gray (5Y6/ } \\
\text { 2) }\end{array}$ & $\begin{array}{l}\text { Common relict bed- } \\
\text { ding; medium } \\
\text { mottles olive } \\
\text { gray }(5 Y 5 / 2) ; \\
\text { distinct medium } \\
\text { nodules dark yel- } \\
\text { lowish brown } \\
\text { (10YR4/4); } \\
\text { weakly calcare- } \\
\text { ous }\end{array}$ & $\begin{array}{l}\text { Intertextic mosepic } \\
\text { to skelsepic com- } \\
\text { mon redeposited } \\
\text { soil clasts, some } \\
\text { quartz, feldspar, } \\
\text { mica and } \\
\text { opaques }\end{array}$ & $\begin{array}{l}\text { Abrupt } \\
\text { smooth to }\end{array}$ \\
\hline
\end{tabular}

clays (Retallack 1977a, 1991b). Even a sandstone (R1868 at $279 \mathrm{~m}$ in Figure 2) had illite peaks insufficiently sharp for deep burial diagenesis (Weaver index 1.4, Kubler index 0.8, Weber index 229). Metamorphic illites have sharp XRD peaks (Weaver index $>2.3$, Kubler index $<0.42$, Weber index $<181$; Frey 1987). Quartz is not so abundant that dissolution between mutual grain contacts is observed in thin section.

Nor is it likely that the silica was mobilized in highly alkaline evaporitic environments that have been inferred from the presence of length-slow chalcedony (quartzine) in carbonates (Folk and Pittman 1971). Numerous exceptions to the association of length-slow chalcedony with evaporites have been found, especially in soils (Arby 1980; Bustillo 1976; Meyer 1983). The noncalcareous and base-poor nature of the paleosols together with the common broadleaf fossil plants (Townrow 1967; Gabites 1985; E.L. Taylor et al. 1990; T.N. Taylor et al. 1990) are evidence of a humid climate.

More likely the silica was derived from biogenic or weathering sources. Horsetails are well known as silica-accumulating plants, and opal from plants is known to be more soluble than quartz (Retallack 1977a). However, the chalcedony root traces do not have the distinctive fluted and jointed morphology of horsetail rhizomes. Some species of Dicroidium may have produced silica phytoliths on the leaves (Retallack 1977a), but no plant is 
TABLE 3.-Description of the type Scott clay paleosol.

\begin{tabular}{|c|c|c|c|c|c|c|}
\hline $\begin{array}{l}\text { Depth } \\
\text { (cm) }\end{array}$ & $\mathrm{Hz}$ & Rock & Color & Other Features & Micromorphology & Contact \\
\hline$+10 \mathrm{~cm}$ & - & Shale & $\begin{array}{l}\text { Gray (5Y5/ } \\
1)\end{array}$ & $\begin{array}{l}\text { Distinct bedding; } \\
\text { common carbo- } \\
\text { naceous remains } \\
\text { of Neocalamites; } \\
\text { non-calcareous }\end{array}$ & $\begin{array}{l}\text { Porphyroskelic ar- } \\
\text { gillasepic; with } \\
\text { some quartz and } \\
\text { opaques, and rare } \\
\text { mica and feldspar }\end{array}$ & $\begin{array}{l}\text { Abrupt } \\
\text { smooth to }\end{array}$ \\
\hline 0 & A & Claystone & $\begin{array}{l}\text { Dark gray } \\
(5 \mathrm{Y} 4 / 1)\end{array}$ & $\begin{array}{l}\text { Common white } \\
\text { (5Y8/1) root trac- } \\
\text { es; claystone } \\
\text { clasts very dark } \\
\text { gray (5Y3/1) and } \\
\text { light gray (5Y5/ } \\
\text { 2); blocky to } \\
\text { platy peds de- } \\
\text { fined by slicken- } \\
\text { sided clay skins } \\
\text { of dark yellowish } \\
\text { brown (10YR4/ } \\
\text { 4); non-calcare- } \\
\text { ous }\end{array}$ & $\begin{array}{l}\text { Porphyroskelic mo- } \\
\text { sepic; with com- } \\
\text { mon quartz, few } \\
\text { feldspar, opaques, } \\
\text { mica and clay- } \\
\text { stone clasts }\end{array}$ & $\begin{array}{l}\text { Gradual irreg- } \\
\text { ular to }\end{array}$ \\
\hline$-16 \mathrm{~cm}$ & $\mathrm{Bw}$ & $\begin{array}{l}\text { Clayey silt- } \\
\text { stone }\end{array}$ & $\begin{array}{r}\text { Light gray } \\
(5 Y 7 / 2)\end{array}$ & $\begin{array}{l}\text { Prominent columnar } \\
\text { peds } 7-8 \mathrm{~cm} \text { in } \\
\text { diameter defined } \\
\text { by silty planes } \\
\text { (silans) of light } \\
\text { gray }(5 \mathrm{Y} 7 / 2) \\
\text { with a core zone } \\
\text { of gray }(5 \mathrm{Y} 6 / 1) \text {; } \\
\text { common white } \\
\text { (5Y8/1) root trac- } \\
\text { es; some medium } \\
\text { blocky subangu- } \\
\text { lar peds defined } \\
\text { by dark gray } \\
\text { (5Y4/1) clay } \\
\text { skins; non-calcar- } \\
\text { eous }\end{array}$ & $\begin{array}{l}\text { Porphyroskelic mo- } \\
\text { sepic; with com- } \\
\text { mon opaques and } \\
\text { quartz, and few } \\
\text { mica and feldspar }\end{array}$ & $\begin{array}{l}\text { Gradual } \\
\text { smooth } \\
\text { contact to }\end{array}$ \\
\hline$-68 \mathrm{~cm}$ & $\mathrm{C}$ & Siltstone & $\begin{array}{r}\text { Light gray } \\
(5 Y 6 / 3)\end{array}$ & $\begin{array}{l}\text { Massive to weakly } \\
\text { bedded with } \\
\text { sparse dark gray } \\
\text { (5Y4/1) mottles } \\
\text { and burrows; } \\
\text { weakly calcare- } \\
\text { ous }\end{array}$ & $\begin{array}{l}\text { Porphyroskelic mo- } \\
\text { sepic; with } \\
\text { quartz, and few } \\
\text { feldspar, mica } \\
\text { and opaques }\end{array}$ & $\begin{array}{l}\text { Abrupt } \\
\text { smooth to }\end{array}$ \\
\hline
\end{tabular}

TABLE 4.-Description of the type Shaun paleosol.

\begin{tabular}{|c|c|c|c|c|c|c|}
\hline $\begin{array}{l}\text { Depth } \\
\text { (cm) }\end{array}$ & $\mathrm{Hz}$ & Rock & Color & Other Features & Micromorphology & Contact \\
\hline$+17 \mathrm{~cm}$ & - & $\begin{array}{l}\text { Sandy silt- } \\
\text { stone }\end{array}$ & $\begin{array}{l}\text { Light gray } \\
(5 Y 7 / 2)\end{array}$ & $\begin{array}{l}\text { Distinct relict bed- } \\
\text { ding; common } \\
\text { white }(5 Y 8 / 1) \\
\text { root traces; few } \\
\text { slickensided clay } \\
\text { skins (argillans) } \\
\text { dark brown } \\
\text { (10YR3/3); } \\
\text { weakly calcare- } \\
\text { ous }\end{array}$ & $\begin{array}{l}\text { Porphyroskelic to } \\
\text { intertextic skelse- } \\
\text { pic; common } \\
\text { quartz and rede- } \\
\text { posited soil } \\
\text { clasts, some } \\
\text { opaques, mica } \\
\text { and feldspar }\end{array}$ & $\begin{array}{l}\text { Abrupt } \\
\text { smooth to }\end{array}$ \\
\hline $0 \mathrm{~cm}$ & A & Claystone & $\begin{array}{l}\text { Gray }(5 \mathrm{Y} 5 / \\
1)\end{array}$ & $\begin{array}{l}\text { Distinct relict bed- } \\
\text { ding; common } \\
\text { fine }(2-3 \mathrm{~mm}) \\
\text { black }(5 \mathrm{Y} 2.5 / 1) \\
\text { root traces; mot- } \\
\text { tles and clay } \\
\text { skins of dark } \\
\text { gray }(5 \mathrm{Y} 4 / 1) \text { de- } \\
\text { fine fine suban- } \\
\text { gular blocky } \\
\text { structure; } \\
\text { non-calcareous }\end{array}$ & $\begin{array}{l}\text { Porphyroskelic in- } \\
\text { sepic; common } \\
\text { redeposited soil } \\
\text { clasts some } \\
\text { quartz and } \\
\text { opaque, little } \\
\text { feldspar and mica }\end{array}$ & $\begin{array}{l}\text { Gradual } \\
\text { smooth to }\end{array}$ \\
\hline$-13 \mathrm{~cm}$ & $\mathrm{C}$ & Siltstone & $\begin{array}{l}\text { Gray (5Y5/ } \\
\text { 1) }\end{array}$ & $\begin{array}{l}\text { Distinct bedding } \\
\text { with clayey lami- } \\
\text { nae of gray } \\
\text { (5Y5/1); non-cal- } \\
\text { careous }\end{array}$ & $\begin{array}{l}\text { Porphyroskelic ar- } \\
\text { gillasepic; with } \\
\text { opaques, quartz } \\
\text { and mica and } \\
\text { some feldspar }\end{array}$ & $\begin{array}{l}\text { Abrupt } \\
\text { smooth to }\end{array}$ \\
\hline
\end{tabular}

TABLE 5.-Textures (volume) percent from point counting and calcareousness (scale of reaction) of Triassic paleosols.

\begin{tabular}{|c|c|c|c|c|c|c|c|c|}
\hline Paleosol & Horizon & Specimen & $\begin{array}{l}\text { Reac- } \\
\text { tion }\end{array}$ & $\underset{\%}{\text { Clay }}$ & $\underset{\%}{\text { Silt }}$ & $\underset{\%}{\text { Sand }}$ & $\begin{array}{c}\text { Grav- } \\
\text { el } \\
\%\end{array}$ & $\begin{array}{l}\text { Tex- } \\
\text { ture }\end{array}$ \\
\hline sandstone & above & R1816 & 1 & 27.0 & 1.2 & 71.8 & 0 & sandy clay loam \\
\hline Norman & A & R1817 & 1 & 82.2 & 16.0 & 1.8 & 0 & clay \\
\hline \multirow[t]{5}{*}{ clay } & $\mathrm{Bw}$ & R1818 & 1 & 71.6 & 18.4 & 10.0 & 0 & clay \\
\hline & $\mathrm{Bw}$ & R1819 & 1 & 52.6 & 15.6 & 31.8 & 0 & clay \\
\hline & $\mathrm{Bw}$ & R1820 & 1 & 74.6 & 14.0 & 11.4 & 0 & clay \\
\hline & $\mathrm{C}$ & R1821 & 1 & 18.4 & 2.2 & 39.0 & 40.4 & sandy loam \\
\hline & $\mathrm{C}$ & R1822 & 1 & 34.6 & 2.6 & 62.4 & 0 & sandy clay loam \\
\hline type & A & R1823 & 1 & 92.4 & 6.0 & 1.6 & 0 & clay \\
\hline Norman & $\mathrm{Bw}$ & R1824 & 1 & 92.6 & 6.8 & 0.6 & 0 & clay \\
\hline \multirow[t]{3}{*}{ clay } & $\mathrm{Bw}$ & R1825 & 1 & 96.2 & 2.8 & 1.0 & 0 & clay \\
\hline & $\mathrm{C}$ & R1826 & 1 & 93.0 & 4.6 & 2.4 & 0 & clay \\
\hline & $\mathrm{C}$ & R1827 & 1 & 65.4 & 8.0 & 26.6 & 0 & clay \\
\hline type & A & R1828 & 1 & 50.4 & 7.6 & 41.8 & 0 & clay \\
\hline Michael & $\mathrm{C}$ & R1829 & 1 & 51.4 & 4.4 & 44.2 & 0 & clay \\
\hline clay & C & R1830 & 1 & 49.4 & 2.4 & 48.2 & 0 & clay \\
\hline Shaun clay & A & R1831 & 1 & 73.8 & 14.6 & 11.6 & 0 & clay \\
\hline type Shaun & A & R1832 & 1 & 81.2 & 15.6 & 3.2 & 0 & clay \\
\hline clay & $\mathrm{C}$ & R1833 & 1 & 73.6 & 18.8 & 7.6 & 0 & clay \\
\hline Shaun clay & A & R1834 & 1 & 84.8 & 11.8 & 3.4 & 0 & clay \\
\hline type Scott & A & R1835 & 1 & 86.0 & 7.2 & 6.8 & 0 & clay \\
\hline \multirow[t]{5}{*}{ clay } & A & R1836 & 1 & 83.8 & 9.0 & 7.2 & 0 & clay \\
\hline & $\mathrm{Bw}$ & R1837 & 1 & 85.8 & 12.0 & 2.2 & 0 & clay \\
\hline & $\mathrm{Bw}$ & R1838 & 1 & 70.2 & 14.2 & 15.6 & 0 & clay \\
\hline & C & R1839 & 1 & 83.8 & 10.6 & 5.6 & 0 & clay \\
\hline & C & R1840 & 1 & 90.0 & 8.6 & 1.4 & 0 & clay \\
\hline Norman & A & R1841 & 1 & 87.7 & 8.4 & 3.0 & 0 & clay \\
\hline
\end{tabular}

Note: Relative scale of calcareousness (1-5) by reaction with 1.2M HCl from Retallack $(1988,1990)$ Standard error of these 500 point counts is about 2 volume \% (Murphy 1983).

known to produce them in roots. Sandstones of the Lashly Formation include mostly volcanic rock fragments, with little indication of tuffaceous glassy grains. Such volcanic glass is also more readily weathered than minerals or rock fragments. In a humid wet climate and volcanic terrain, groundwater could have carried moderately elevated concentrations of silicic acid, but there is no evidence from veining or mineralization of local geothermal activity needed for highly silica-charged waters.

Although the silica could be from plants or weathering, there is still a

TABLE 6.-Mineral composition (volume percent) from point counting petrographic thin sections of Triassic paleosols.

\begin{tabular}{|c|c|c|c|c|c|c|c|c|c|}
\hline Paleosol & Horizon & Specimen & Clay & $\begin{array}{c}\text { Feld- } \\
\text { spar }\end{array}$ & Mica & $\begin{array}{l}\text { Vol- } \\
\text { canic } \\
\text { Rock }\end{array}$ & $\begin{array}{l}\text { Weath- } \\
\text { ered } \\
\text { Rock }\end{array}$ & Opaque & Quartz \\
\hline sandstone & above & R1816 & 27.8 & 2.8 & 2.2 & 1.2 & 17.2 & 4.6 & 44.2 \\
\hline \multirow[t]{6}{*}{ Norman clay } & A & R1817 & 82.8 & - & 0.4 & - & 5.8 & 2.2 & 8.8 \\
\hline & $\mathrm{Bw}$ & R1818 & 71.2 & 0.6 & 3.4 & 2.6 & 0.8 & 1.2 & 20.2 \\
\hline & Bw & R1819 & 54.0 & 1.4 & 7.4 & 1.6 & 3.2 & 2.4 & 30.0 \\
\hline & Bw & R1820 & 73.6 & 1.4 & 3.2 & 3.4 & 0.8 & 3.4 & 14.2 \\
\hline & $\mathrm{C}$ & R1821 & 19.0 & 2.0 & 1.4 & 5.8 & 45.6 & 3.4 & 25.8 \\
\hline & C & R1822 & 35.6 & 4.0 & 3.0 & 14.6 & 7.6 & 3.6 & 31.6 \\
\hline \multirow{5}{*}{$\begin{array}{l}\text { type Norman } \\
\text { clay }\end{array}$} & A & R1823 & 91.2 & - & 1.4 & - & - & 1.4 & 6.0 \\
\hline & Bw & R1824 & 91.6 & - & 1.6 & - & - & 2.6 & 4.2 \\
\hline & $\mathrm{Bw}$ & R1825 & 95.6 & - & 0.4 & - & - & 1.2 & 2.8 \\
\hline & $\mathrm{C}$ & R1826 & 92.8 & 0.2 & 0.8 & - & - & - & 6.2 \\
\hline & C & R1827 & 65.2 & 1.0 & 2.2 & - & 2.8 & 3.8 & 25.0 \\
\hline \multirow{3}{*}{$\begin{array}{l}\text { type Michael } \\
\text { clay }\end{array}$} & A & R1828 & 51.4 & 1.8 & 5.0 & 1.8 & 5.2 & 3.6 & 31.2 \\
\hline & $\mathrm{C}$ & R1829 & 52.6 & 1.8 & 4.4 & 4.4 & 4.6 & 3.8 & 28.4 \\
\hline & $\mathrm{C}$ & R1830 & 49.8 & 4.4 & 2.0 & 4.8 & 11.2 & 2.6 & 25.2 \\
\hline Shaun clay & A & R1831 & 75.4 & 1.0 & 1.6 & - & 10.0 & 5.0 & 7.0 \\
\hline type Shaun & A & R1832 & 74.0 & 0.2 & 0.6 & - & 16.2 & 5.6 & 3.4 \\
\hline clay & $\mathrm{C}$ & R1833 & 74.4 & 2.4 & 7.0 & - & - & 9.6 & 6.6 \\
\hline Shaun clay & A & R1834 & 87.0 & 0.8 & 1.2 & - & 0.2 & 7.8 & 3.0 \\
\hline type Scott & A & R1835 & 81.0 & 0.4 & 1.2 & - & 0.4 & 5.6 & 11.0 \\
\hline \multirow[t]{5}{*}{ clay } & A & R1836 & 82.0 & - & 2.0 & - & 0.6 & 1.8 & 13.6 \\
\hline & $\mathrm{Bw}$ & R1837 & 87.6 & 0.6 & 0.2 & 0.4 & 0.6 & 5.2 & 5.4 \\
\hline & Bw & R1838 & 71.6 & 2.4 & 6.2 & - & 1.4 & 2.4 & 15.6 \\
\hline & $\mathrm{C}$ & R1839 & 84.2 & 1.0 & 1.4 & - & - & 10.6 & 2.2 \\
\hline & C & R1840 & 90.4 & 0.4 & 2.6 & - & - & 1.8 & 4.8 \\
\hline Norman clay & A & R1841 & 88.6 & - & 3.4 & - & - & 3.5 & 4.2 \\
\hline
\end{tabular}


TABLE 7.-Major-element chemical analyses and loss on ignition (weight percent) of Triassic paleosols.

\begin{tabular}{|c|c|c|c|c|c|c|c|c|c|c|c|c|c|c|c|}
\hline Paleosol & Horizon & Specimen & $\mathrm{SiO}_{2}$ & $\mathrm{TiO}_{2}$ & $\mathrm{Al}_{2} \mathrm{O}_{3}$ & $\mathrm{Fe}_{2} \mathrm{O}_{3}$ & $\mathrm{FeO}$ & $\mathrm{MnO}$ & $\mathrm{MgO}$ & $\mathrm{CaO}$ & $\mathrm{Na}_{2} \mathrm{O}$ & $\mathrm{K}_{2} \mathrm{O}$ & $\mathrm{P}_{2} \mathrm{O}_{5}$ & LOI & Total \\
\hline type & $\mathrm{A}$ & $\mathrm{R} 1823$ & 61.31 & 0.59 & 17.54 & 3.47 & 4.43 & 0.04 & 1.14 & 0.45 & 1.02 & 2.74 & 0.04 & 5.41 & 98.75 \\
\hline \multirow[t]{4}{*}{ Norman } & $\mathrm{Bw}$ & R1824 & 62.57 & 0.63 & 17.52 & 2.93 & 3.72 & 0.04 & 0.98 & 0.64 & 1.2 & 2.53 & 0.08 & 5.40 & 98.78 \\
\hline & $\mathrm{Bw}$ & R1825 & 58.11 & 0.67 & 19.12 & 3.28 & 4.73 & 0.05 & 0.95 & 0.80 & 0.79 & 1.82 & $<0.03$ & 6.85 & 97.79 \\
\hline & C & R1826 & 59.73 & 0.69 & 19.34 & 3.21 & 3.65 & 0.09 & 0.91 & 0.85 & 0.86 & 1.91 & 0.04 & 7.26 & 99.03 \\
\hline & $\mathrm{C}$ & R1827 & 65.37 & 0.68 & 17.36 & 1.89 & 3.02 & 0.05 & 0.66 & 0.72 & 1.19 & 2.14 & 0.14 & 5.65 & 99.26 \\
\hline type & A & R1828 & 65.78 & 0.60 & 17.80 & 1.84 & 2.46 & 0.05 & 0.77 & 0.75 & 1.23 & 2.43 & 0.03 & 5.17 & 99.24 \\
\hline \multirow[t]{2}{*}{ Michael } & $\mathrm{C}$ & R1829 & 69.70 & 1.18 & 13.44 & 1.46 & 3.72 & 0.16 & 0.73 & 0.87 & 1.35 & 1.60 & $<0.03$ & 3.74 & 98.42 \\
\hline & $\mathrm{C}$ & $\mathrm{R} 1830$ & 68.31 & 0.59 & 15.26 & 1.76 & 2.60 & 0.07 & 0.85 & 0.81 & 1.80 & 1.97 & $<0.03$ & 4.26 & 98.62 \\
\hline Shaun & A & R1831 & 65.49 & 0.65 & 16.29 & 2.40 & 2.88 & 0.08 & 1.00 & 0.71 & 1.56 & 2.51 & 0.11 & 4.57 & 98.65 \\
\hline type & A & $\mathrm{R} 1832$ & 62.02 & 0.68 & 19.08 & 2.36 & 2.36 & 0.04 & 1.18 & 0.70 & 1.13 & 2.98 & 0.06 & 6.12 & 99.02 \\
\hline Shaun & $\mathrm{C}$ & R1833 & 65.05 & 0.68 & 17.17 & 1.12 & 2.46 & 0.05 & 1.18 & 0.87 & 1.01 & 2.19 & 0.14 & 5.65 & 97.89 \\
\hline Shaun & A & R1834 & 60.28 & 0.75 & 20.01 & 1.97 & 2.88 & 0.12 & 1.36 & 0.95 & 0.61 & 2.65 & $<0.03$ & 7.40 & 99.35 \\
\hline type & A & R1835 & 60.39 & 0.86 & 22.73 & 1.23 & 0.28 & 0.05 & 0.36 & 1.36 & 1.09 & 1.47 & 0.10 & 8.71 & 98.48 \\
\hline \multirow[t]{5}{*}{ Scott } & A & $\mathrm{R} 1836$ & 58.66 & 0.85 & 22.39 & 1.21 & 1.05 & 0.05 & 0.43 & 1.34 & 0.95 & 1.97 & 0.05 & 8.85 & 97.94 \\
\hline & $\mathrm{Bw}$ & R1837 & 66.38 & 0.84 & 16.20 & 1.70 & 2.04 & 0.04 & 0.55 & 0.92 & 0.57 & 1.53 & $<0.03$ & 6.33 & 97.36 \\
\hline & $\mathrm{Bw}$ & R1838 & 61.19 & 0.67 & 18.75 & 1.64 & 2.91 & 0.05 & 0.81 & 1.05 & 0.68 & 1.95 & 0.10 & 7.10 & 97.28 \\
\hline & C & R1839 & 60.75 & 0.68 & 18.31 & 2.39 & 4.15 & 0.05 & 0.96 & 0.68 & 0.73 & 2.50 & 0.09 & 5.77 & 97.63 \\
\hline & $\mathrm{C}$ & $\mathrm{R} 1840$ & 62.97 & 0.60 & 16.84 & 2.17 & 3.93 & 0.03 & 0.92 & 0.53 & 0.92 & 2.87 & 0.13 & 4.67 & 97.08 \\
\hline error & $\boldsymbol{\sigma}$ & all & 0.25 & 0.02 & 0.17 & 0.15 & 0.08 & 0.005 & 0.05 & 0.10 & 0.05 & 0.01 & 0.004 & - & - \\
\hline
\end{tabular}

Note: Analyses from inductively-coupled plasma-atomic fusion, ferrous ammonium sulfate titration and combustion at $1000^{\circ} \mathrm{C}$ for 4 hrs by Bondar-Clegg \& Co., North Vancouver, B.C. Errors from 59 analyses of standard rock CANMET SY-3.

need for a concentration mechanism for selective silicification of root traces, peat fragments, and fossil wood in the Lashly Formation. Considering indications of low-temperature silicification early during burial and local pyrite cubes, a likely mechanism for silicification of root traces, peat, and wood is as a consequence of plant decay by sulfate-reducing bacteria (Birnbaum and Wireman 1984; Birnbaum et al. 1986). This process requires chemically reducing conditions and an organic substrate. During shallow burial the banded silicification may reflect seasonal warmth for decay and fluctuating silica concentrations in interstitial fluids. Such a microbially mediated origin also implies that the root traces that became filled with silica were the last crop of roots before burial, because earlier generations of roots would have decayed away without falling within the groundwater zone of anaerobic sulfate-reducing bacteria and silica accumulation. Furthermore, hydrated silica produced by bacteria in stagnant soil water would be flushed out during the dry season of plant growth, whereas in buried soils it would be dehydrated and recrystallized to chalcedony.

The overall pattern of roots includes a stout and deeply penetrating network most like that found today under woodland of well drained ground (Weaver 1919). It is neither a surface mat, patchy laterally, nor especially uneven in its size distribution, unlike root distribution in tundra, taiga,

TABLE 8.-Trace element analyses (ppm) and bulk density $\left(\mathrm{g} \cdot \mathrm{cm}^{-3}\right)$ of Triassic paleosols.

\begin{tabular}{|c|c|c|c|c|c|c|c|c|c|}
\hline Paleosol & $\begin{array}{l}\text { Hori- } \\
\text { zon }\end{array}$ & Specimen & $\mathrm{Ba}$ & $\mathrm{Nb}$ & $\mathrm{Rb}$ & $\mathrm{Sr}$ & Y & $\mathrm{Zr}$ & $\mathrm{g} \cdot \mathrm{cm}^{-3}$ \\
\hline type & A & R1823 & 793 & 12 & 184 & 106 & 57 & 208 & 2.21 \\
\hline \multirow[t]{4}{*}{ Norman } & Bw & R1824 & 645 & 14 & 167 & 145 & 56 & 221 & 2.21 \\
\hline & $\mathrm{Bw}$ & R1825 & 597 & 15 & 150 & 164 & 36 & 238 & - \\
\hline & C & R1826 & 557 & 15 & 148 & 176 & 45 & 248 & 2.28 \\
\hline & $\mathrm{C}$ & R1827 & 422 & 16 & 135 & 156 & 50 & 379 & 2.37 \\
\hline type & A & R1828 & 570 & 14 & 153 & 127 & 32 & 291 & 2.29 \\
\hline \multirow[t]{2}{*}{ Michael } & $\mathrm{C}$ & R1829 & 389 & 16 & 105 & 115 & 40 & 901 & 2.21 \\
\hline & $\mathrm{C}$ & R1830 & 525 & 13 & 121 & 147 & 58 & 270 & 2.23 \\
\hline Shaun & A & R1831 & 565 & 13 & 150 & 128 & 70 & 293 & 2.25 \\
\hline type & A & R1832 & 653 & 14 & 185 & 126 & 52 & 246 & 2.28 \\
\hline Shaun & $\mathrm{C}$ & R1833 & 496 & 15 & 134 & 108 & 49 & 342 & 2.37 \\
\hline Shaun & A & R1834 & 533 & 17 & 164 & 114 & 49 & 272 & 2.36 \\
\hline type & A & R1835 & 498 & 21 & 135 & 167 & 42 & 432 & 2.40 \\
\hline \multirow[t]{5}{*}{ Scott } & A & R1836 & 556 & 22 & 153 & 171 & 42 & 440 & 2.41 \\
\hline & $\mathrm{Bw}$ & R1837 & 324 & 20 & 122 & 116 & 35 & 429 & 2.31 \\
\hline & $\mathrm{Bw}$ & R1838 & 437 & 17 & 125 & 146 & 42 & 347 & 2.27 \\
\hline & $\mathrm{C}$ & R1839 & 587 & 15 & 165 & 123 & 33 & 239 & 2.30 \\
\hline & C & R1840 & 608 & 14 & 170 & 83 & 35 & 247 & 2.20 \\
\hline error & $\sigma$ & all & 16 & 0.6 & 1 & 3 & 0.6 & 7 & 0.02 \\
\hline
\end{tabular}

Note: Trace elements are X-ray fluorescence and same analyst as Table 6, with errors from 59 samples of standard CANMET SO-2. Bulk densities are by Evelyn Krull using clod method with error from 10 replicates
of R1839. savanna, monsoon-forest, or rain-forest vegetation. It is likely that these distinctive white-root beds largely represent the fossil plant association dominated by Dicroidium odontopteroides (Townrow 1967; Gabites 1985; T.N. Taylor et al. 1990; E.L. Taylor et al. 1990), and that it was a humid, cold temperate woodland.

FOSSIL SOILS

\section{Pedotypes and Paleosol Associations}

Two distinct assemblages of paleosols were found in the Lashly Formation: a coal-measure association with fossil plants (Member $\mathrm{C}$ only) and a green claystone association with white root traces (Members A-D). Paleosols of the coal-measure association are described by Gabites (1985, paleosol type 7), but our study focused on the green-claystone association of the lower Lashly Formation (Members A and B), in which we found four distinctly different kinds of paleosols, or pedotypes (Fig. 2). Weakly developed pedotypes of the green-claystone association include sandy profiles of the Michael pedotype (paleosol type 4 of Gabites 1985) and shaly profiles of the Shaun pedotype (paleosol type 5 of Gabites 1985). Thicker paleosols of weak to moderate development that probably supported woodland vegetation include the Norman pedotype (paleosol type 6 of Gabites 1985 ) with locally prominent slickensides and surface undulation, and the Scott pedotype (2 of Gabites 1985), with prismatic structure some 7-10 $\mathrm{cm}$ wide and $40-50 \mathrm{~cm}$ high outlined by silty planes. These four pedotype names are meant only as field labels, and are nongenetic terms.

\section{Burial Alteration}

Alteration of paleosols during burial and metamorphism can seriously compromise paleoenvironmental interpretation (Retallack 1991a, 1991b). Although some of the paleosols include coal and carbonaceous fossil plant remains (Gabites 1985), others with abundant large white root traces have little carbonaceous material. This observation and their distinctly green hue are evidence of early burial decomposition of organic matter and burial gleization of the paleosols (Retallack 1991b). This may have changed noncarbonaceous yellow and brown soils into green paleosols.

Burial also has altered the paleosols by cementation, illitization, and compaction. Silica cement is especially obvious in the white root traces (Figs. 3-6), but is also more pervasive in the paleosols. At least some of this silica cement formed very early during burial, because permineralized fossil wood has remained uncompacted by subsequent deep burial (Gabites 1985; E.L. Taylor and Taylor 1993). One source of such cement is illiti- 

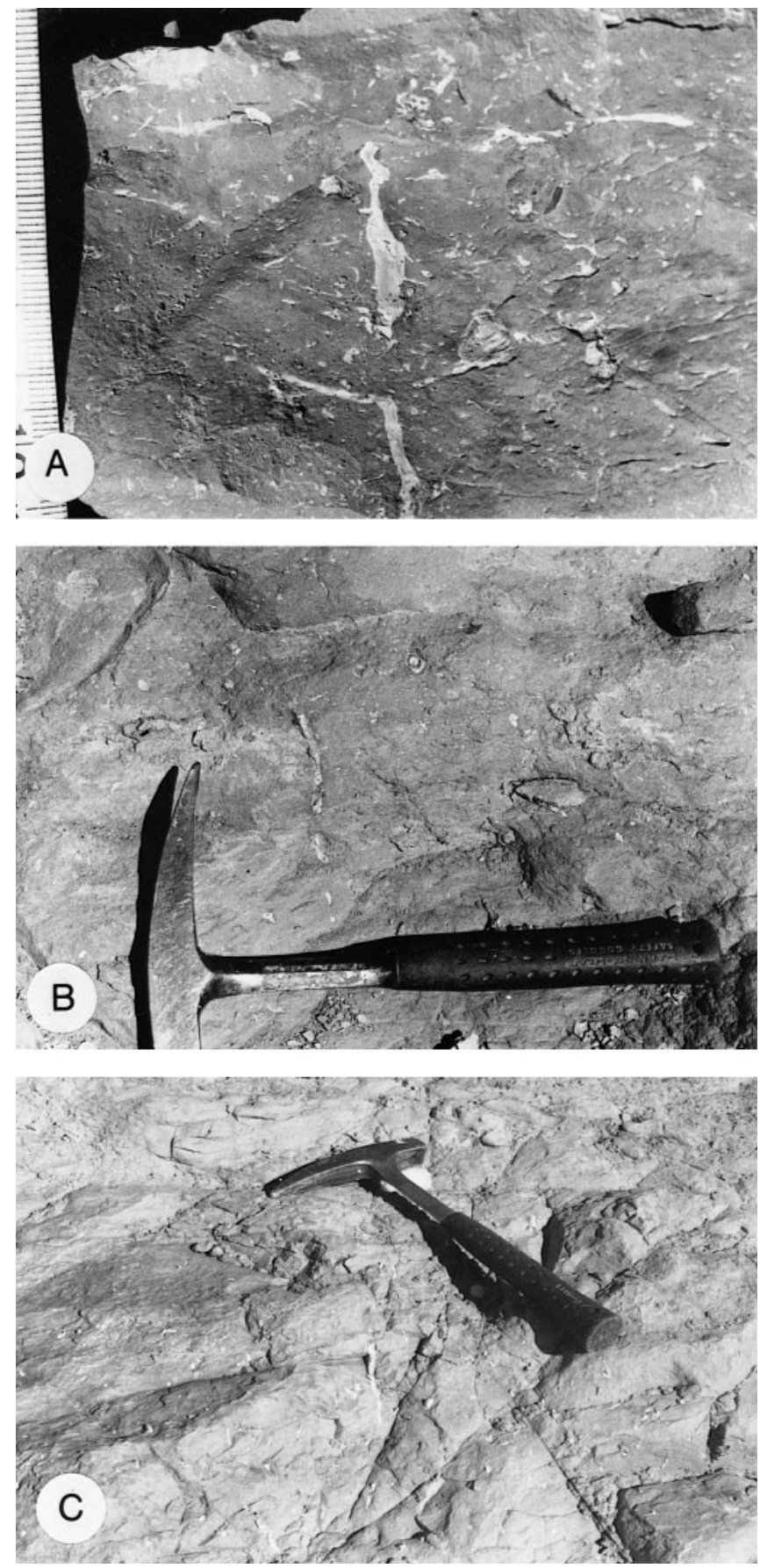

FIG. 3.-White fossil root traces of the Lashly Formation, Antarctica (all at level of Specimen R1841). Scale is in millimeters and geological hammers are $25 \mathrm{~cm}$ long.

zation of smectite clays (Eberl et al. 1990), but this could not have been pervasive because of the width of illite peaks (Fig. 7), as already discussed.

Burial compaction would have been significant and can be estimated using a formula of Sclater and Christie (1980):

$$
C=\frac{0.5}{\frac{0.49}{\mathrm{e}^{\mathrm{D} / 3.7}}-1}
$$

where $C$ is compaction as a fraction and $D$ is depth of burial in kilometers.
Paleosols at the base of the Lashly Formation could have been overlain by as much as $520 \mathrm{~m}$ of the formation found elsewhere in southern Victoria Land, and $600 \mathrm{~m}$ of Jurassic volcanics, an estimate compatible with $2 \mathrm{~km}$ of overburden needed to explain the low-volatile bituminous coals of the Weller Coal Measures $170 \mathrm{~m}$ stratigraphically below the paleosols (Coates et al. 1990). Taking $2 \mathrm{~km}$ as an estimate for the equation given above gives $82 \%$ compaction of the paleosols due to burial. Observations of clastic dikes in paleosols versus shales indicate that this is a maximal likely compaction (Caudill and Driese 1996).

\section{Chemical and Mineralogical Composition}

Paleosols of the Lashly Formation show variations in chemical and petrographic composition both within and between profiles that indicate weathering. Mineral weathering in the form of etch pits and encrusting clays are prominent on feldspars within volcanic rock fragments (Fig. 4C, D). Primary bedding is disrupted by clay skins (Fig. 9B, C; argillans of Brewer 1976) and silt infiltration structures (Fig. 9A; siltans). These structures reflect cracking of the soil with drying or freezing, and modification of the crack surfaces. Nevertheless, the degree of variation in chemical and mineral composition within individual paleosol profiles is relatively muted (Fig. 8) compared with the range of alteration known from soils and paleosols (Retallack 1990). None of them show pronounced subsurface accumulations of clay, alumina, or carbonate.

The greenish gray color and dominance of ferrous over ferric iron in the paleosols indicate a surprising degree of chemical reduction for paleosols that must have been drained episodically to allow deep penetration of roots and soil cracks. Cool humid climate with low evapotranspiration, slow drainage, and a shallow water table in an extensive floodplain are likely, but also needed are chemically reducing agents such as vegetative cover and microbial gleization during early burial.

A humid paleoclimate can be inferred from the noncalcareous and basepoor chemical composition of the paleosols, like Early Triassic paleosols from Antarctica (Barrett and Fitzgerald 1986) and eastern Australia (Jensen 1975; Retallack 1977b). They have the chemical composition of soils of humid climates (pedalfers rather than pedocals of Marbut 1935), but are not intensely leached like soils of excessively rainy climates. Quantitative estimates of paleoprecipitation can be gained from the molecular ratio of bases/alumina (B) in the B horizons of North American soils, which can be shown to be related to mean annual rainfall $(\mathrm{P}, \mathrm{mm})$ according to the following formula (Ready and Retallack 1995):

$$
\mathrm{P}=-759 \mathrm{~B}+1300
$$

with correlation coefficient of 0.7 and standard deviation $(\sigma)$ of \pm 174 $\mathrm{mm}$. Estimates of rainfall for the B horizon of the type Norman clay and type Scott clay are 935-1016 and 986-1050 mm, respectively. In round figures and including regression error this is $800-1200 \mathrm{~mm}$ per annum.

This indication of wet climate is not contradicted by sand crystals found in paleochannels of Member A of the Lashly Formation (279 m in Figure 2), because these are not calcite, gypsum, or barite like sand crystals of arid regions (MacFayden 1950; Maglione 1981). XRD peaks at 9.69, 3.11, 3.33 , and $4.73 \AA$ (in order of intensity) indicate that this mineral is rhomboclase (Chen 1977). This is a sulfate $\left[\mathrm{HFe}\left(\mathrm{SO}_{4}\right)_{2}\right]$ formed from the weathering of pyrite (Nickel and Nichols 1991). The rhomboclase sand crystals are comparable in size and shape to nodules of pyrite and jarosite found in sandstones of the Weller Coal Measures and Feather Conglomerate in the Allan Hills, and could have formed by redeposition and oxidation of those nodules. In the Lashly Formation, pyrite was not found in the paleochannels, but is locally found in paleosols.

\section{Cracking Structures}

Some Norman paleosols show sand-filled cracks, reaching down $50 \mathrm{~cm}$ into the profile. These cracks commonly emanate from a part of the profile 

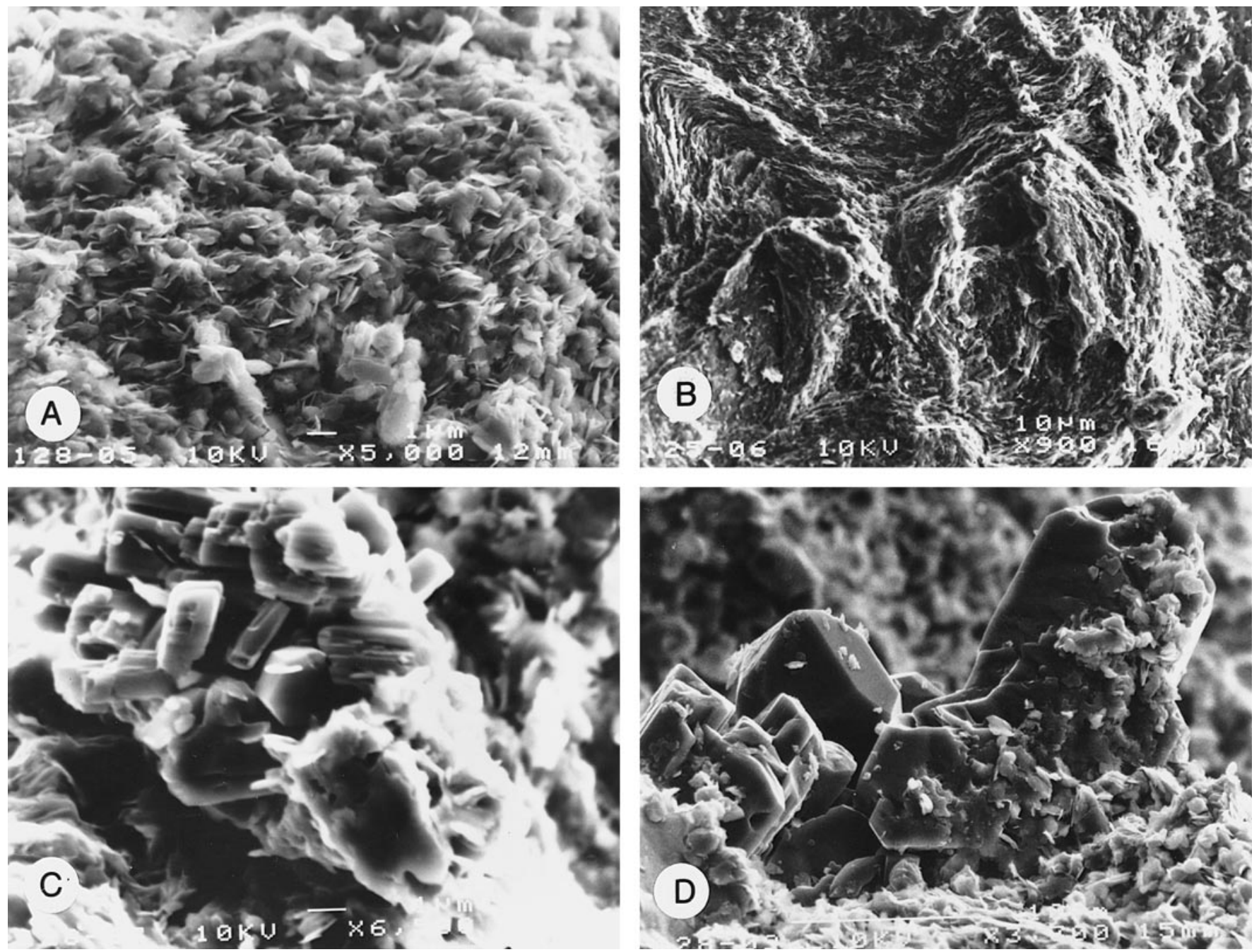

FIG. 4.-Scanning electron micrographs of minerals in white root traces of the Lashly Formation, Antarctica: A) clay-encrusted chalcedony fibers; B) chalcedony (massive) and clay (laminated); C) sanidine in volcanic rock fragment; D) orthoclase in volcanic rock fragment. Specimen numbers are R1838 (C) and R1841 (others).

that is elevated into a low ridge, separated at distances of $1-2 \mathrm{~m}$ by shallow surficial swales (Fig. 10). Some Norman paleosols also show extensive shallowly curved slickensided planes, in some cases distinctly basinshaped. These structures are similar to the gilgai microrelief and its subsurface or mukkara structures of Vertisols.

These structures of Norman paleosols are much more subtle than in modern Vertisols, which have more marked microrelief and more abundant slickensides defining lentil peds (Krishna and Perumal 1948). Also lacking in petrographic thin sections are the pervasive randomly oriented planes of highly birefringent clays found in Vertisols (Holzhey et al. 1974). Nevertheless, these deep cracking structures indicate similar processes of shrinking and swelling, even if not so severe or in action for so long. Gilgaimukkara are features of soils with smectites in climates with a pronounced dry season (Paton 1974). A short dry period or several dry spells within the growing season also may explain the deeply penetrating woody root traces in paleosols that have remained chemically reduced. Considering the wet climate indicated by base-poor chemical composition and associated coaly paleosols, the dry season is unlikely to have been a profound moisture deficit or to have lasted more than a few weeks during the summer.

\section{Vertical Jointing}

A prominent feature of the Scott pedotype is closely spaced $(7-8 \mathrm{~cm}$ apart) vertical joints extending through some $60 \mathrm{~cm}$ or so of the subsurface of the paleosol (Fig. 11). These define prismatic peds of soil-science jargon (Brewer 1976). They are outlined by cracks filled with silt grains similar to those higher in the profile, or illuviation silans in soil jargon (Brewer 1976). Such features have been noted before in other Triassic paleosols of Victoria Land (as gammate and glossic structures of Gabites 1985; Fitzgerald and Barrett 1986).

Prismatic peds differ from columnar peds in lacking domed tops. Columnar peds are a characteristic feature of natric soil horizons (of Soil Survey Staff 1975, 1990; McCahon and Miller 1996), but this explanation does not work well for Scott paleosols because there is no evidence of sodium enrichment (Fig. 8) or abundant smectite clays (Fig. 7). Columnar and prismatic peds are also features of fragipans, which are loamy subsurface horizons that are low in organic matter, high in bulk density compared with covering soil, and cemented so that they are very hard when dry and brittle even when wet (Soil Survey Staff 1975). This explanation is supported by a variety of field, petrographic, and chemical observations of Scott paleosols. Redeposited claystone clasts are found at several levels within paleosols and in paleochannels of the Lashly Formation. Root traces in Scott paleosols tend to be molded around the peds, as if they were more difficult to penetrate than the cracks between them. Silica cement and fine clays are suspected as the primary causes of hardness in Quaternary fragipans (Nettleton et al. 1968), and both can be documented in fossil root 


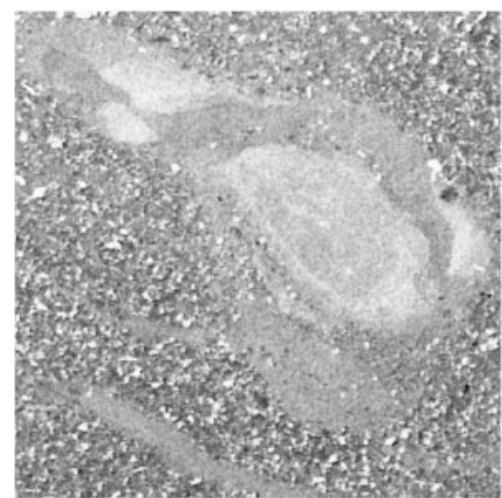

Si

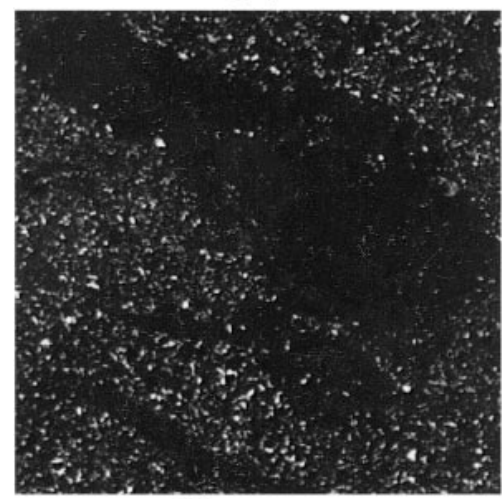

$\mathrm{Na}$

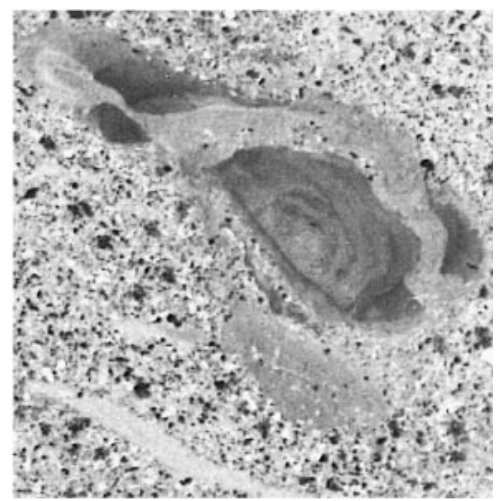

Al

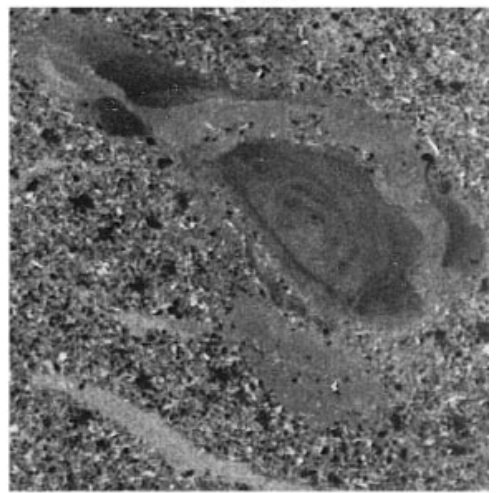

K

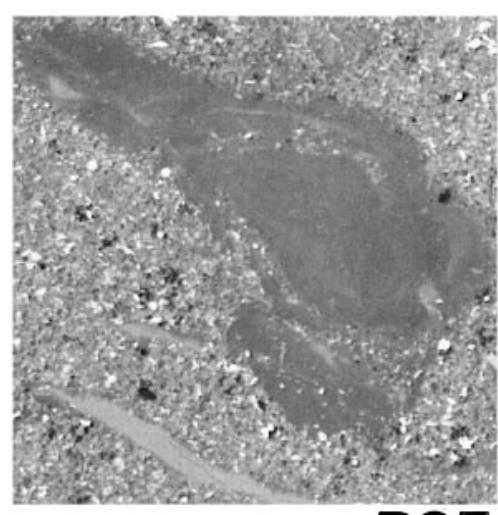

BSE
FIG. 5.-Microprobe chemical maps for silicon $(\mathrm{Si})$, aluminum $(\mathrm{Al})$, sodium $(\mathrm{Na})$, potassium (K), and back-scattered image (BSE) of a white root trace from the Lashly Formation, Antarctica, showing concentrically interlaminated chalcedony and illite (Specimen R1841) traces of early burial origin in the Lashly Formation (Fig. 5). Furthermore, colloidal cement bridges can also be seen as isolated pockets within the matrix of the columnar peds (Fig. 9B, lower right).

Fragipans are found mainly in moderately to strongly developed soils and take at least 2-5 kyr to form (Ciolkosz et al. 1979; Hall et al. 1982). Estimates on the low end of this range are compatible with the obliteration of bedding seen in the Scott pedotype. Fragipans also are common in soils with slow drainage (Buol et al. 1980), as seems likely for the green and chemically reduced Scott paleosols. Finally, fragipans, unlike other hardened horizons in soils such as duripans and petrocalcic or petrogypsic horizons, are found mainly in forested soils of humid climates (Ciolkosz et al. 1989; Lindbo and Veneman 1989), as seems likely considering the chemical composition and root traces of Scott paleosols.

The origin of fragipans in Quaternary soils remains poorly understood. Some fragipans appear to be cemented volcanic tuffs (Flores-Román et al. 1992), but there are no shards or other fresh tuffaceous material in
Scott paleosols of the Lashly Formation. More than just a humid climate or forest vegetation is needed to encourage the formation of fragipans because they degrade with time under humid forested regimes of leaching, clay illuviation, or podzolization (Steele et al. 1965; Ciolkosz et al. 1989). Such observations have suggested that many fragipans may be relict from different conditions in the past, perhaps as old as the last glacial maximum of $15 \mathrm{ka}$. Repeated movement of a freezing front through this horizon may be the process that swept silt out to the margins of the pan, where it formed a system of conduits for colloidal cements (Buol et al. 1980). Frost cracking may explain the vesicular, prismatic, and platy structures of fragipans, defined by silty more porous planes through which ultrafine clay could be washed down into the profile. A frost barrier in or near the pan could also pond water at shallow levels within the soil during early spring melt. In a forested soil with thick leaf litter this water could become stagnant enough to encourage sulfate-reducing bacteria to generate patchy silica cement by mechanisms that have 

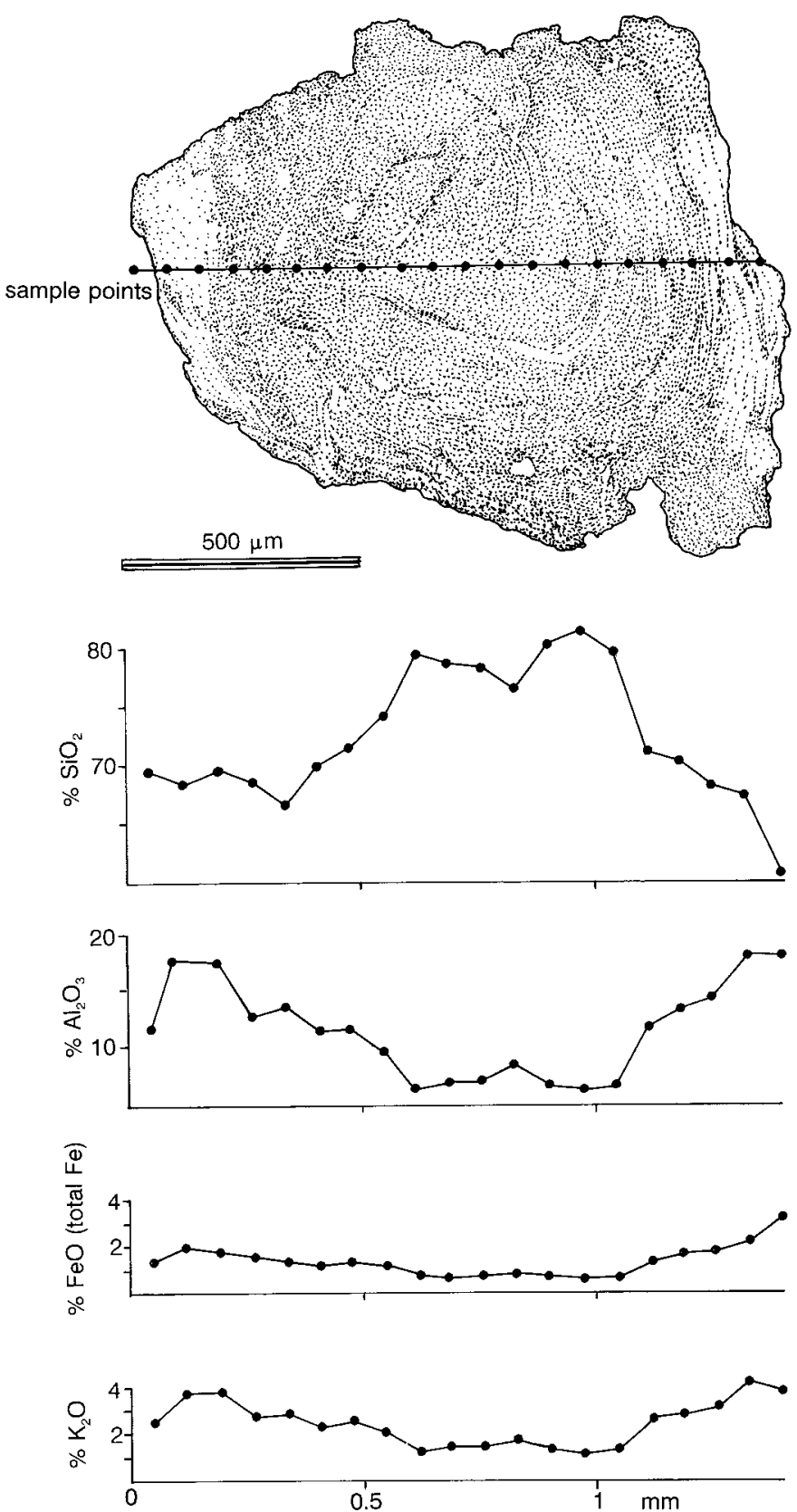

FIg. 6.-Microprobe traverse of white root trace from the Lashly Formation, Antarctica, showing concentrically interlaminated chalcedony and illite (Specimen R1841).

been duplicated experimentally (Birnbaum and Wireman 1984; Birnbaum et al. 1986). By this model, prismatic peds of the Scott pedotype can be regarded as indications of a seasonally cold climate.

\section{Landscape Paleoecology}

Paleosols of the lower Lashly Formation show a consistent occurrence within sedimentary facies and with respect to fossil plant associations, so that a reconstruction of their sedimentary setting and vegetation can be attempted in a manner comparable to landscape ecology (Fig. 12). Within each fining-upward fluvial cycle, channel deposits are followed by levee deposits with Shaun and Michael pedotypes, and then floodplain deposits with Scott and Norman pedotypes. Shaun and Michael paleosols have abun-
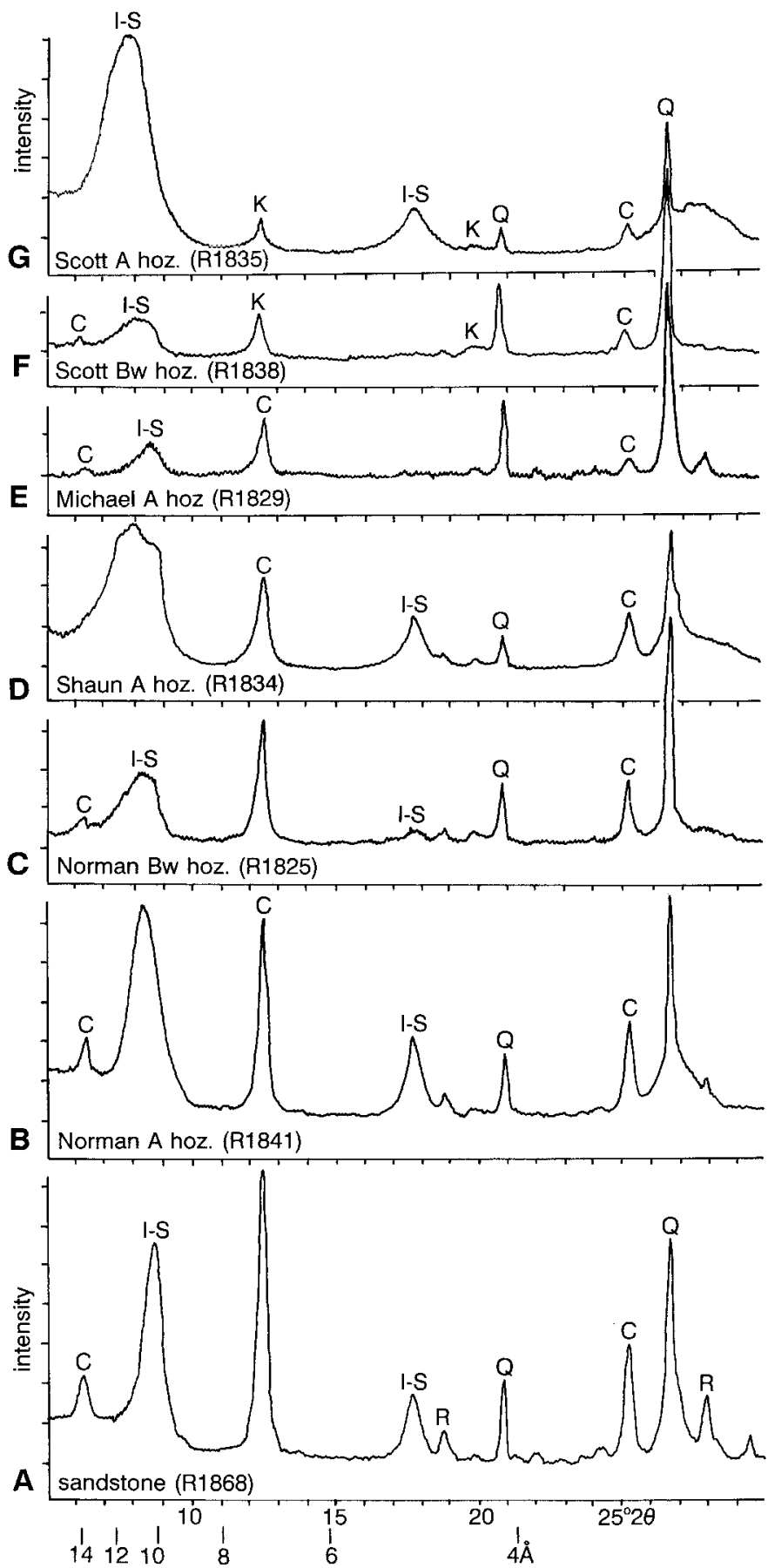

FIG. 7.-X-ray diffractometer traces of paleosols with poorly crystallized clays and sediments with well crystallized clay from the Lashly Formation, Antarctica. The following minerals can be identified: chlorite $(\mathrm{C})$, mixed layer illite-smectite $(\mathrm{I}-\mathrm{S})$, kaolinite $(\mathrm{K})$, rhomboclase $(\mathrm{R})$, and quartz $(\mathrm{Q})$.

dant relict bedding, microtextures that are intertextic and insepic to skelsepic, and few clay skins (Tables 1-4). These are all indications of very weak development, due to a short time of soil formation and plant communities early in ecological succession after disturbance (Retallack 1990). In contrast, Scott and Norman paleosols are more massive and bioturbated, with porphyroskelic and mosepic microtextures, more clay films (Tables 1-4), and evidence of chemical and mineralogical weathering (Fig. 9). Development comparable to that of Norman and Scott pedotypes is found in 


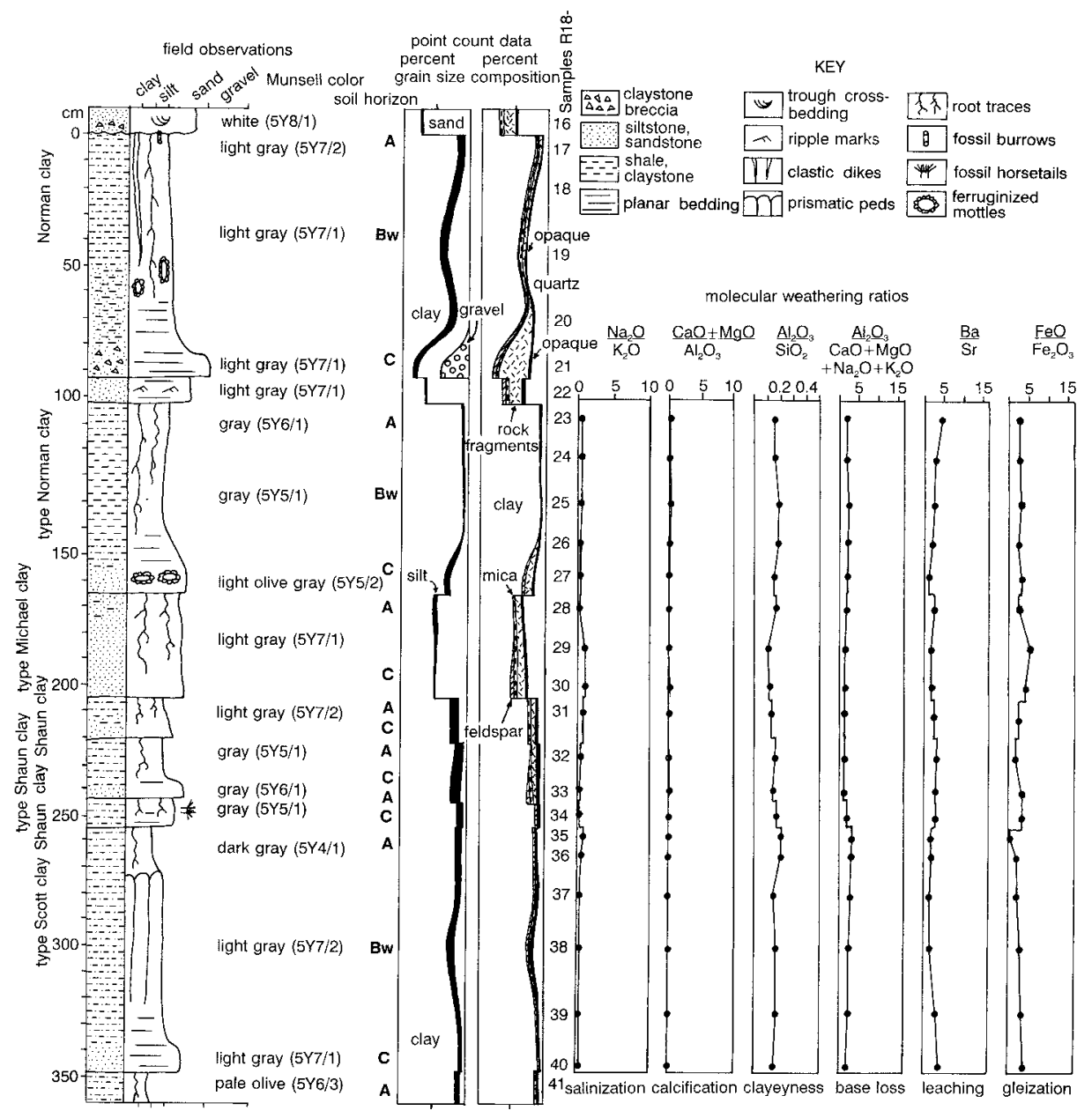

FIG. 8.-Measured section, Munsell colors, soil horizons, grain size, mineral composition, and selected molecular weathering ratios of the type Norman, Michael, Shaun, and Scott pedotypes and other paleosols from $258-263 \mathrm{~m}$ in the measured section (Fig. 2) in the Allan Hills, Antarctica. modern gray soils of the Mississippi Delta, which are some 2000 years old under oak forest (Matthews 1983, 1984). Mississippi soils only 10-100 years old under grass and willow scrub show relict bedding comparable to that of Michael and Shaun pedotypes. Such estimates of duration are typical for comparable soils in a variety of environments (Retallack 1990). Within the braided-stream depositional environment of Zwartz and Woolfe (1996), the very weakly developed soils formed on near-channel sandy bars of crevasse splays and levees (Michael pedotype) and on clay-bottom swales of the levee system (Shaun). The better developed paleosols represent floodplains that were seasonally wet (Norman pedotype) and frozen (Scott).

This depositional landscape and soilscape can be related to three recurring associations of fossil leaves found in the lower Lashly Formation.

1. Neocalamites carrerei forms nearly monospecific assemblages in Shaun paleosols (258 m in Figure 2; Allan Hills locality 16, Mt Bastion 31, Portal Mt 2 of Gabites 1985). This herbaceous, marginally aquatic vegetation can be considered a part (synusia) of the Dicroidietum odontopteroidium xylopterosum of Retallack (1977c).

2. Dicroidium odontopteroides dominates a diverse assemblage of other species of Dicroidium, including the xeromorphic D. elongatum, with occasional ferns (Cladophlebis) and conifers (Heidiphyllum, Rissikia; $258 \mathrm{~m}$ in section $200 \mathrm{~m}$ southwest of line of section, Fig. 2; Allan Hills localities 13, 17, Mt Bastion 32, Portal Mt 1 of Gabites 1985; level 3 of E.L. Taylor et al. 1990). This plant assemblage was found in shale lenses and heterolithic low-angle cross-beds, representing floodplain ponds and levee deposits, respectively. Fossil logs of modest size (up to $8 \mathrm{~cm}$ in diameter) were seen within the lower Lashly Formation, and larger stumps and logs have been recorded from the upper Lashly Formation (Gabites 1985). The wood is pycnoxylic with pronounced growth rings, and the Dicroidium leaves have petiolar abscission scars, indicating they were deciduous trees (Retallack and Dilcher 1988; Meyer-Berthaud et al. 1992, 1993). This is the Dicroidietum odontopteroidium xylopterosum association interpreted as broadleaf woodland and forest (Retallack 1977c, 1978, 1987).

3. Heidiphyllum elongatum is found in very low-diversity assemblages, usually within Michael paleosols (Portal Mt 32 of Gabites 1985). The cones of this plant (Telemachus) have also been found near the Beardmore Glacier (E.L. Taylor and Taylor 1988), and were woody like those of conifer trees (Retallack 1981; Anderson and Anderson 1983). This Heidiphylletum association is interpreted as a colonizing woodland (Retallack 1977c, 1978, 1987).

These plant associations also have paleoclimatic implications, because they are more diverse than would be found in frigid, dry, or salty environments. On the other hand, diversity of communities (3 listed above) and within communities (22 species of Gabites 1995) is lower than would be expected in subtropical or warm temperate regions, even within Middle Triassic Gondwanan fossil floras of New Zealand, Australia, South Africa, and South America (Retallack 1977c, 1987; Anderson and Anderson 1983).

\section{Analogous Modern Soilscapes}

Another way of exploring the paleoenvironmental significance of paleosols is to find comparable soilscapes. The assembled petrographic and chemical data on paleosols of the Lashly Formation (Fig. 8) allow classification (Table 9), within the soil taxonomy of the U.S. Soil Conservation Service (Soil Survey Staff 1975, 1990), the soil map of the Food and 

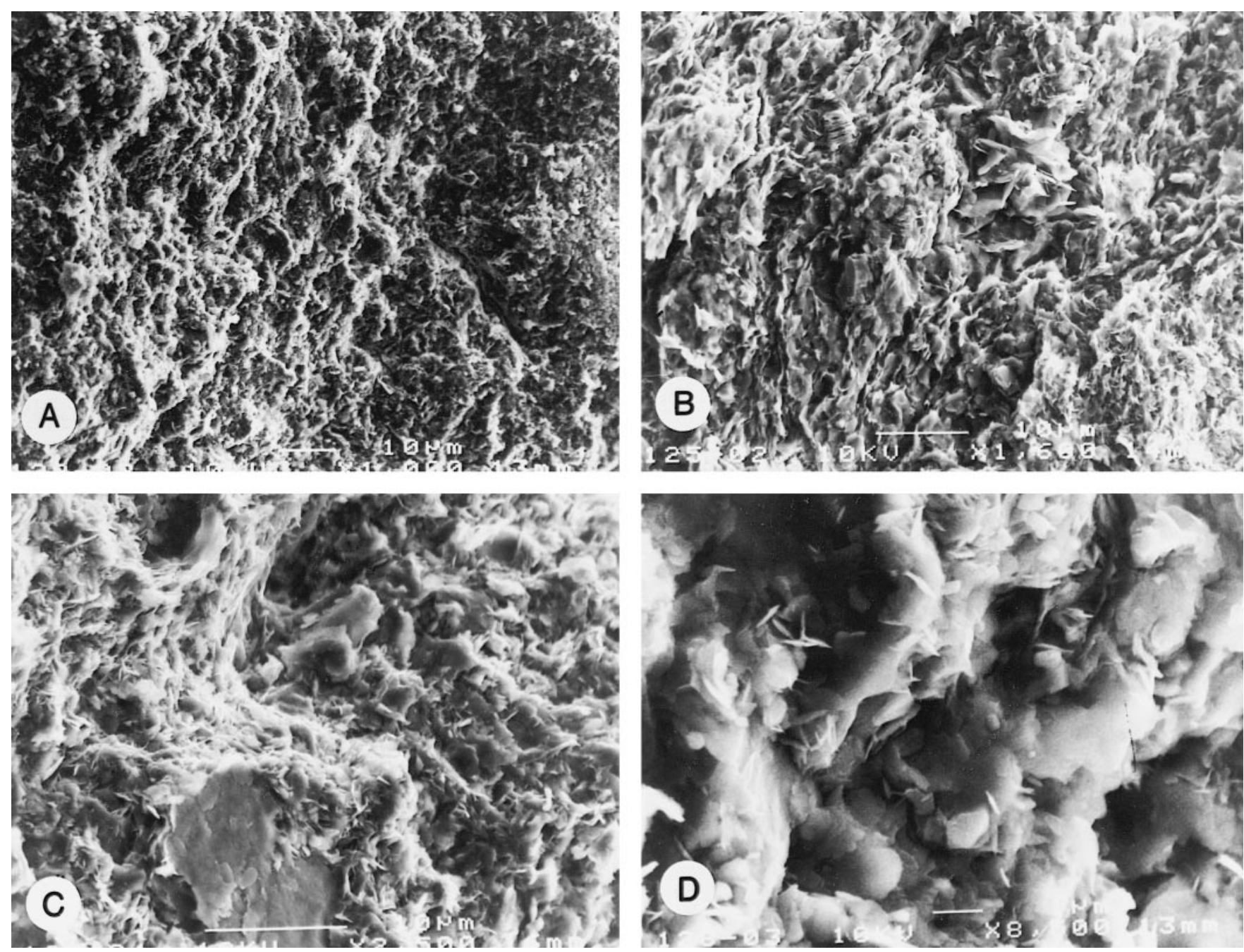

FIG. 9.-Scanning electron micrographs of silt infiltration structures (siltans) and clay skins (argillans) of paleosols in the Lashly Formation, Antarctica: A) siltan of coated grains; B) narrow skin of coarse clay; C) laminated clay skins; D) illitic clay of matrix. Specimen number for B is R1838. Others are from R1841.

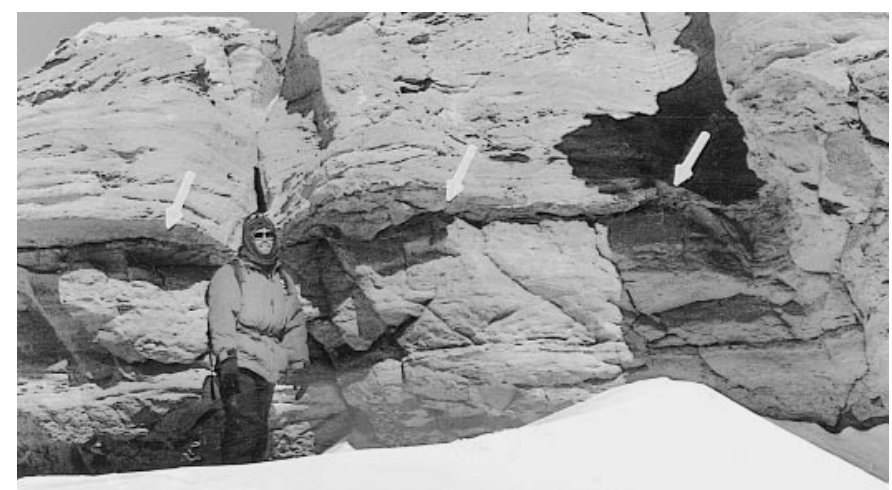

FIG. 10.-Ridges of microrelief (at arrows) in a Norman paleosol of the Lashly Formation, Antarctica. Scott Robinson is for scale.
Agriculture Organization of UNESCO (FAO 1975, 1978a, 1978b, 1981) and other classifications (Stace et al. 1968; Northcote 1974; Isbell 1993) Shaun and Michael paleosols show minimal development like U.S. Entisols. They are clayey and sandy respectively, and so probably were U.S. Fluvents and Psamments. The greater homogenization but weak development of Norman and Scott pedotypes are most like U.S. Inceptisols. Both Norman and Scott pedotypes lack the prominent mottles and tabular root systems of Aquepts, the plow-features of Plaggepts, and the pervasive oxidation of iron found in Tropepts and Ochrepts. The suborder Umbrept offers a compromise of drab color with evidence of slow drainage. The lack of dispersed organic matter in the paleosols expected for Umbrepts can be attributed to burial gleization (a process described by Retallack 1991a, 1991b). Among Umbrepts the prismatic structures with siltans of the Scott pedotype are most like Fragiumbrepts and the cracking and silt infiltration structures of Norman paleosols are like Xerumbrepts. These are soils of high latitudes and altitudes in the United States, where they form on geomorphic surfaces of Holocene or latest Pleistocene age on glacial sediments. They form largely in humid, seasonally cold regions under coniferous forest. Such soils are common in high mountains of the western states and summer-dry parts of the Pacific Coast (Soil Survey Staff 1975).

The FAO classification is even more useful because its soil maps of the world can be used to identify particular analogous modern soilscapes. In 

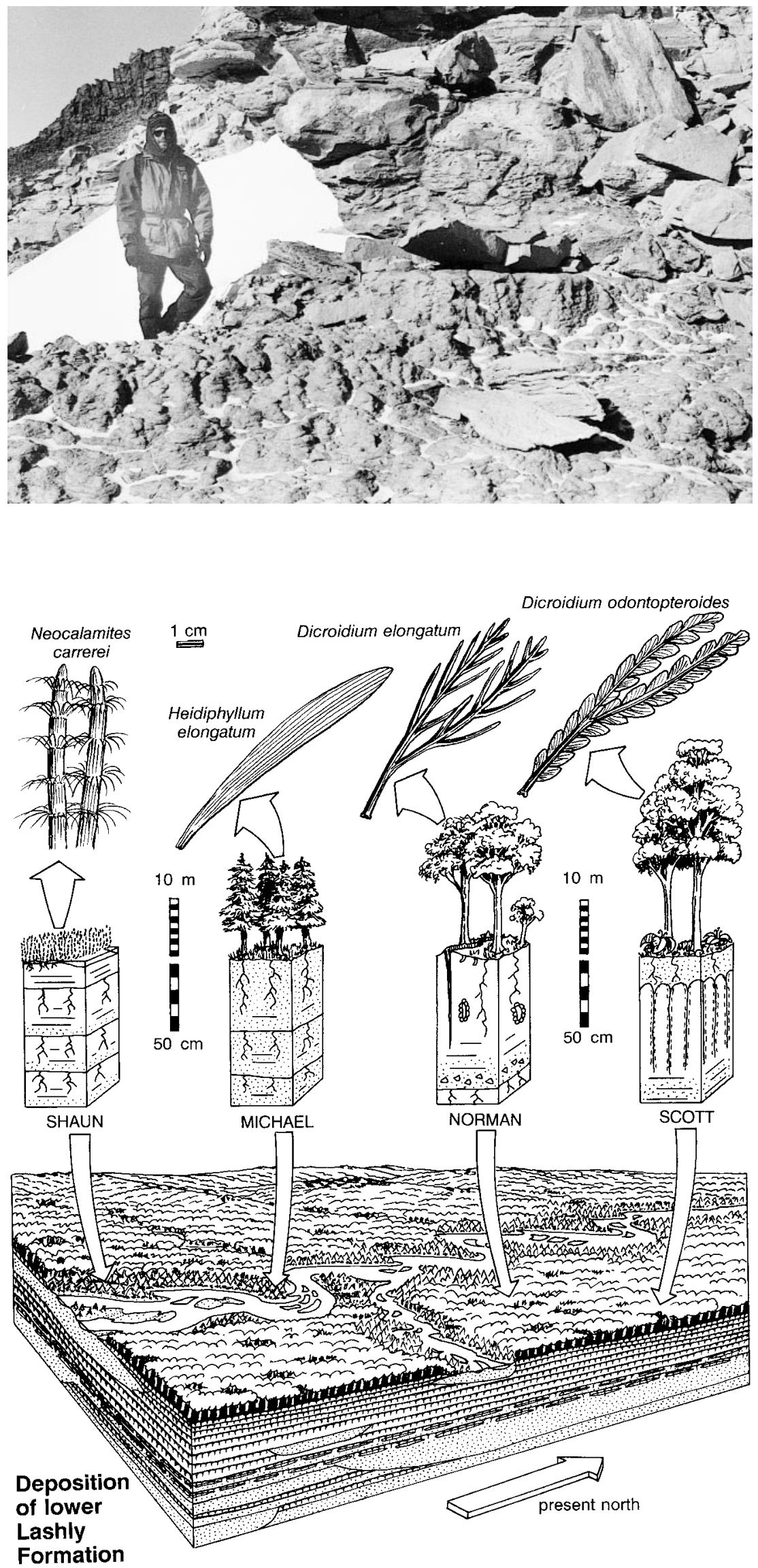

FIG. 11_-Prismatic structure (foreground, below and in front of figure) in Scott pedotype of the Lashly Formation, Antarctica. Scott Robinson is for scale.
FIG. 12.-Reconstructed paleoenvironment of the lower Lashly Formation of Antarctica during the Middle Triassic. Soils are reconstructed from data presented here, but fossil plants are from Gabites (1985) and sedimentary setting is from Collinson et al. (1994), Zwartz and Woolfe (1996), and Woolfe et al. (1996). 
TABLE 9.-Identification of Triassic paleosols of the lower Lashly Formation.

\begin{tabular}{|c|c|c|c|c|c|c|}
\hline $\begin{array}{l}\text { Pedo- } \\
\text { type }\end{array}$ & Diagnosis & $\begin{array}{l}\text { Old } \\
\text { Austra- } \\
\text { lian } \\
\text { (Stace } \\
\text { et al. } \\
1968 \text { ) }\end{array}$ & $\begin{array}{c}\text { New } \\
\text { Australian } \\
\text { (Isbell } \\
1993 \text { ) }\end{array}$ & $\begin{array}{l}\text { North- } \\
\text { cote } \\
\text { Key } \\
\text { (North- } \\
\text { cote, } \\
1974 \text { ) }\end{array}$ & $\begin{array}{l}\text { FAO Map } \\
\text { (FAO 1974) }\end{array}$ & $\begin{array}{c}\text { U.S. } \\
\text { Taxonomy } \\
\text { (Soil Sur- } \\
\text { vey Staff } \\
\text { 1990) }\end{array}$ \\
\hline Michael & $\begin{array}{l}\text { Green sandstone } \\
\text { with root traces }\end{array}$ & $\begin{array}{c}\text { Alluvial } \\
\text { soil }\end{array}$ & $\begin{array}{l}\text { Orthic Rudo- } \\
\text { sol }\end{array}$ & Um1.21 & $\begin{array}{l}\text { Eutric Fluvi- } \\
\text { sol }\end{array}$ & Psamment \\
\hline Norman & $\begin{array}{l}\text { Green silty clay- } \\
\text { stone with white } \\
\text { root traces and } \\
\text { slightly more } \\
\text { clayey subsurface } \\
\text { (Bw) horizon }\end{array}$ & $\begin{array}{l}\text { Grey } \\
\text { clay }\end{array}$ & $\begin{array}{l}\text { Chernic Te- } \\
\text { nosol }\end{array}$ & Gn3.91 & $\begin{array}{l}\text { Vertic Cambi- } \\
\text { sol }\end{array}$ & Xerumbrept \\
\hline Shaun & $\begin{array}{l}\text { Gray bedded shale } \\
\text { with root traces }\end{array}$ & $\begin{array}{c}\text { Alluvial } \\
\text { soil }\end{array}$ & $\begin{array}{l}\text { Stratic Rudo- } \\
\quad \text { sol }\end{array}$ & Uf1.21 & $\begin{array}{l}\text { Dystric Fluvi- } \\
\text { sol }\end{array}$ & Fluvent \\
\hline Scott & $\begin{array}{l}\text { Green silty clay- } \\
\text { stone with pris- } \\
\text { matic peds in } \\
\text { subsurface (Bw) } \\
\text { horizon }\end{array}$ & $\begin{array}{l}\text { Gray } \\
\text { clay }\end{array}$ & $\begin{array}{l}\text { Orthic Teno- } \\
\quad \text { sol }\end{array}$ & Gn4.51 & $\begin{array}{l}\text { Humic Cam- } \\
\text { bisol }\end{array}$ & Fragiumbrept \\
\hline
\end{tabular}

this classification Michael and Shaun paleosols are very weakly developed like Fluvisols. Their differing mineral and chemical compositions (Fig. 12) are compatible with interpretation as Eutric Fluvisols and Dystric Fluvisols, respectively. The better developed Norman and Scott paleosols lack diagnostic horizons of most soil orders other than Cambisols and Gleysols. Persistence of ferrous iron and green-gray color are compatible with a Gleysol interpretation, but against it is the general lack of high-chroma mottles, and presence of deeply penetrating root traces, vertic structures, and bleached prismatic peds. The Norman pedotype with its cracking patterns is best identified as a Vertic Cambisol, but could also be regarded as a vertic variant of a Humic Cambisol, an identification most appropriate for the Scott pedotype. Such Cambisols are not common today, but comparable soilscapes can be found around lakes Mälaren and Vänern, and on the coast near Västernik and north of Göteborg, all in southern Sweden (map units $\mathrm{Bv} 22-2 \mathrm{a}$ and $\mathrm{Bv} 23-2 \mathrm{a}$ of FAO 1981). Here they have formed on glacial sediments in a cold to cool temperate, humid climate, under mixed coniferous-deciduous boreal forests around the lakes and Baltic beech forests along the coast. Spruce (Picea) and pine (Pinus) are dominant on siliceous soils, but the more clayey and nutrient rich soils are covered by deciduous trees including elm (Ulmus), linden (Tilia), maple (Acer), aspen (Populus), birch (Betula), and hazel (Corylus). Also comparable to paleosols of the Lashly Formation are soils in the Wairau River Valley near Blenheim in the South Island of New Zealand (Bh 20-21a of FAO 1978b) and high in the Southern Alps of Australia from Mt Buller to Mt Feathertop in Victoria and Mt Kosciusko to Kiandra in New South Wales (Bh 19-2c of FAO 1978b). These areas also are cold to cool temperate, seasonally snowy and humid. Vegetation in the Australian Alps includes woodland of snow gum (Eucalyptus pauciflora), with local heath and alpine grassland, whereas in the northern part of the South Island of New Zealand it is beech forest.

Triassic paleosols of this former Gondwanan continental interior are not like Arctic soils of today, but similar to soils in southern Sweden (latitude $57-60^{\circ} \mathrm{N}$ ), the South Island of New Zealand (latitude $41-42^{\circ} \mathrm{S}$ ), and the southern Alps of Australia (latitude $35-38^{\circ} \mathrm{S}$, but elevations of 2000-2500 $\mathrm{m})$. This is puzzling when one considers the likely paleolatitude of the Lashly Formation in the central Transantarctic Mountains today. Recent estimates vary between $69-73^{\circ} \mathrm{S}$ for $240 \mathrm{Ma}: 69^{\circ} \mathrm{S}$ with the pole offshore from the southern tip of South America (Scotese 1994); $71^{\circ} \mathrm{S}$ with the pole offshore from the central Transantarctic Mountains (Barrett 1991); and $73^{\circ} \mathrm{S}$ with the pole in central New South Wales, Australia (Veevers et al. 1994). The equator-to-pole decline in temperature must have been less marked in the Triassic than today.

\section{a Paleoclimatic anomaly}

During the Middle Triassic the Lashly Formation of southern Victoria Land was at a latitude of $69-73^{\circ} \mathrm{S}$ (Barrett 1991; Scotese 1994; Veevers et al. 1994) and in the interior of the Gondwana supercontinent. It was some $600 \mathrm{~km}$ from the Andean-style Gondwanide fold belt that separated it from the Eopacific Ocean and thousands of kilometers south of subtropical northern Gondwana coasts (Collinson et al. 1994). Parts of Siberia are now similarly placed geographically. For example, the central Lena River between Zigansk and Dzardzan at $68-72^{\circ} \mathrm{N}$ is about $1200 \mathrm{~km}$ inland of the Pacific Ocean behind eastern Siberian fold mountain ranges, $500 \mathrm{~km}$ east of the central Siberian uplands, and $500 \mathrm{~km}$ south of the Arctic Ocean. The climate of this region is frigid, with a short growing season. At Ust Maistoje there are only five months above freezing, mean annual temperature is $-10^{\circ} \mathrm{C}$, with summer temperatures of $18^{\circ} \mathrm{C}$, winters of $-41^{\circ} \mathrm{C}$, and mean annual rainfall of $152 \mathrm{~mm}$ (Walter et al. 1975). The vegetation of this region is a stunted open woodland (taiga) of larch (Larix dahurica), with Siberian pine (Pinus sibirica) and scrub alder (Alnus fruticosa). The soils include Gelic Cambisols (map unit Bx 4-2a of FAO 1978a) on rolling interfluves, with Eutric Fluvisols (Je 79-2a) in the floodplain of the Lena River. Lena floodplain soils also include Eutric Gleysols and Mollic Gleysols, as well as inclusions of Eutric Histosols. Many of these soils show permafrost features (FAO 1978a), which can be obvious in paleosols (Williams 1986) but were not seen in paleosols of the Lashly Formation. Thus the Middle Triassic paleoclimate of Antarctica was not as frigid as expected from paleogeographic considerations.

Paleoclimatic modeling of Pangea during the Middle Triassic also fails to duplicate conditions indicated by fossil plants and soils of the Lashly Formation of Victoria Land (Table 10). A computer model by Kutzbach

TABLE 10.—Paleoenvironmental interpretation of Triassic paleosols of the lower Lashly Formation.

\begin{tabular}{|c|c|c|c|c|c|c|}
\hline $\begin{array}{l}\text { Pedo- } \\
\text { type }\end{array}$ & Paleoclimate & Former Vegetation & Former Animals & Paleotopography & $\begin{array}{l}\text { Parent } \\
\text { Material }\end{array}$ & $\begin{array}{l}\text { Time for } \\
\text { Formation }\end{array}$ \\
\hline Michael & $\begin{array}{l}\text { Not sufficiently developed to be } \\
\text { an indicator }\end{array}$ & $\begin{array}{l}\text { Gymnosperms, early in the ecological } \\
\text { succession after disturbance }\end{array}$ & Not known & $\begin{array}{l}\text { Sandy bars, levee tops and cre- } \\
\text { vasse splays of ancient rivers }\end{array}$ & Volcaniclastic sand & 5-100 years \\
\hline Norman & $\begin{array}{l}\text { Humid ( } 800-1200 \mathrm{~mm} \text { mean an- } \\
\text { nual precipitation) seasonally } \\
\text { snowy, with summer dry spells, } \\
\text { cold temperate }\end{array}$ & $\begin{array}{l}\text { Gymnosperm woodland of open struc- } \\
\text { ture: probably deciduous woodlands } \\
\text { dominated by Dicroidium odonto- } \\
\text { pteroides found in associated pond } \\
\text { deposits }\end{array}$ & $\begin{array}{l}\text { Burrowing insects or spi- } \\
\text { ders }\end{array}$ & $\begin{array}{l}\text { Moderately well drained clayey } \\
\text { floodplains }\end{array}$ & $\begin{array}{l}\text { Volcaniclastic silt and } \\
\text { clay }\end{array}$ & $1000-5000$ years \\
\hline Shaun & $\begin{array}{l}\text { Not sufficiently developed to be } \\
\text { an indicator }\end{array}$ & $\begin{array}{l}\text { Herbaceous vegetation early in ecolog- } \\
\text { ical succession around pond and riv- } \\
\text { er margins, dominated by horsetails } \\
\text { (Neocalamites) }\end{array}$ & Not known & $\begin{array}{l}\text { Low lying swales and lakes in } \\
\text { levee and floodplain }\end{array}$ & $\begin{array}{l}\text { Volcaniclastic silt and } \\
\text { clay }\end{array}$ & 5-100 years \\
\hline Scott & $\begin{array}{l}\text { Humid ( } 800-1200 \mathrm{~mm} \text { mean an- } \\
\text { nual precipitation) seasonally } \\
\text { snowy, with locally frozen } \\
\text { ground, cold temperate }\end{array}$ & $\begin{array}{l}\text { Gymnosperm woodland of open struc- } \\
\text { ture: probably deciduous woodlands } \\
\text { dominated by Dicroidium odonto- } \\
\text { pteroides found in associated pond } \\
\text { deposits }\end{array}$ & Not known & $\begin{array}{l}\text { Moderately well drained clayey } \\
\text { floodplains }\end{array}$ & $\begin{array}{l}\text { Volcaniclastic silt and } \\
\text { clay }\end{array}$ & $1000-5000$ years \\
\hline
\end{tabular}


and Gallimore (1989) gave Victoria Land a mean annual range of temperature of $50^{\circ} \mathrm{C}$, with summers of $15^{\circ} \mathrm{C}$ and winters of $-35^{\circ} \mathrm{C}$, and mean annual precipitation of $300 \mathrm{~mm}$. This frigid dry paleoclimate was at odds with paleontological and sedimentological evidence (Yemane 1993), so future runs explicitly included estimates of greenhouse warming due to atmospheric carbon dioxide. The computer model by Fawcett et al. (1994) used minimal snow cover, high relief $(2 \mathrm{~km})$, and elevated carbon dioxide (1000 ppm or three times present), to give winter temperatures in Victoria Land of $-30^{\circ} \mathrm{C}$ and summer temperatures of $25^{\circ} \mathrm{C}$. The model by Wilson et al. (1994) used minimal snow cover, moderate relief $(1.5 \mathrm{~km})$, and elevated carbon dioxide (1360 ppm, or four times present), to give southern Victoria Land during the early Late Triassic (Carnian) a summer temperature of $20^{\circ} \mathrm{C}$, a winter temperature of $-45^{\circ} \mathrm{C}$, and a solid permafrost zone within the soil. A later model by Kutzbach (1994) used high atmospheric carbon dioxide (1650 ppm or five times modern value), very low topography $(500 \mathrm{~m})$, and minimal snow cover to compute that Victoria Land had a mean annual temperature of $-5^{\circ} \mathrm{C}$, with winter temperatures of $-30^{\circ} \mathrm{C}$ and summer temperature of $25^{\circ} \mathrm{C}$, mean annual rainfall of $1100 \mathrm{~mm}$, and mean annual soil moisture of $8 \mathrm{~cm}$. The extreme temperature fluctuation and permafrost conditions seen today in Siberia are unavoidable even when models are run under conditions of high atmospheric carbon dioxide, elevation, and lack of snow that should mitigate such extremes.

Fossil soils discussed here indicate a climate more like that of southern Sweden, the Australian Alps, or New Zealand. For example, Stockholm in southern Sweden has a mean annual temperature of $5.9^{\circ} \mathrm{C}$ and mean annual precipitation of $569 \mathrm{~mm}$, with only four snow months. Hotham Heights in southeastern Australia has a mean annual temperature of $6.1^{\circ} \mathrm{C}$ and mean annual rainfall of 1260, with five snow months. Blenheim in New Zealand has a mean annual temperature of $12^{\circ} \mathrm{C}$ and mean annual rainfall of 645 $\mathrm{mm}$, but only rare snow. These are cool temperate climates in the classification of Walter et al. (1975), not the frigid climate of the Siberian interior. It could be that modeling and paleosol comparisons disagree because of different regimes of cloudiness (Slingo and Slingo 1991), differing Milankovitch orbital forcings (Kutzbach 1994), or the presence of large lakes (Yemane 1993). The models may be profitably rerun with data on soil moisture and ecosystem albedo based on soils analogous to the paleosols reported here.

An overlooked factor that may account for this anomaly is lower primary productivity of vegetation, particularly in wetland habitats. Globally reduced productivity could affect world climate through a higher atmospheric ratio of $\mathrm{CO}_{2} / \mathrm{O}_{2}$, lower atmospheric water vapor, lower soil moisture, and higher overall albedo. There are several indications of low productivity in the Early and Middle Triassic. During the Middle Triassic only thin coal seams are known in a period of recovery from the Early Triassic, when there was no coal anywhere in the world (Retallack et al. 1996). The Middle Triassic is also a period of recovery of carbon isotopic composition of organic matter in nonmarine basins (Morante et al. 1994; Morante 1996) and in the diversity of plant life following abrupt decimation by extinctions at the Permian-Triassic boundary (Retallack 1995). The nadir of plant productivity and zenith of anomalous polar warmth was probably during the Early Triassic, as indicated by paleosols similar to Luvisols in Australia (Retallack 1977a, 1997a), southern Victoria Land (Retallack et al. 1997a), and the central Transantarctic Mountains (Retallack et al. 1997b). These paleosols indicating anomalous polar warmth can be contrasted with nonanomalous Gelic Histosols at high paleolatitudes in the mid-Permian of Antarctica (Krull and Retallack 1995), Late Permian of New South Wales (Retallack 1997b) and Late Triassic of Tasmania (Smyth 1980). Anomalously warm polar regions with Humic and Vertic Cambisols during the Middle Triassic may be a lingering effect of the early Mesozoic greenhouse (Zeigler et al. 1993). Whatever its cause, the warmer and milder than expected Middle Triassic paleoclimate of Antarctica remains an anomaly that can now be reassessed using paleosols.

\section{ACKNOWLEDGMENTS}

We thank Evelyn Krull, Scott Robinson, Shaun Norman, and helicopter pilots of VXE6 for assistance in the field and Roy Torley and Michael Shaffer for laboratory assistance. Work was funded by National Science Foundation grant OPP9315228.

\section{REFERENCES}

Anderson, J.M., And Anderson, H.M., 1983, Palaeoflora of southern Africa, Molteno Formation (Triassic) Vol. 1. Introduction. Part 2. Dicroidium: Rotterdam, A.A. Balkema, 227 p.

Arbey, F., 1980, Les formes de la silice et l'identification des évaporites dans les formations silicifiés: Centres Recherche Exploration-Produccion Elf Aquitaine, Bulletin, v. 4, p. 309 365.

BAKKER, R.T., 1986, The dinosaur heresies: New York, William Morrow, 481 p.

Ballance, P.F., 1977, The Beacon Supergroup in the Allan Hills, central Victoria Land, Antarctica: New Zealand Journal of Geology and Geophysics, v. 20, p. 1003-1016.

BARRETT, P.J., 1991, Antarctica and global climatic change: a geological perspective, in Harris, C.M., and Stonehouse, B., eds., Antarctica and Global Change: Cambridge, U.K., Scott Polar Institute and Belhaven Press, p. 35-50.

Barrett, P.J., And FitzGerald, P.G., 1986, Deposition of the lower Feather Conglomerate, a Permian braided river deposit in southern Victoria Land, Antarctica, with notes on paleogeography: Sedimentary Geology, v. 45, p. 199-208.

Birnbaum, S.J., AND WiREMAN, J.W., 1984, Bacterial sulfate reduction and $\mathrm{pH}$ : implications for early diagenesis: Chemical Geology, v. 43, p. 143-149.

Birnbaum, S.J., Wireman, J.W., and Borowski, R., 1986, Silica precipitation induced by the anaerobic sulfate producing bacterium Desulfovibrio desulfuricans: effects upon cell morphology and implications for preservation, in Crick, R.E., ed., Origin, Evolution and Modern Aspects of Biomineralization in Plants and Animals: New York, Plenum Press, p. 507-526.

BREWER, R., 1976, Fabric and Mineral Analysis of Soils, 2nd Edition: New York, Krieger, 482 p.

Buol, S.W., Hole, F.D., and McCracken, R.J., 1980, Soil Genesis and Classification: Ames, Iowa, Iowa University Press, $406 \mathrm{p}$.

Bustillo, M.A., 1976, Texturas de las rocas silíceas inorgánicas en ambiente continental y significado genético: Estudios Geológicos, v. 22, p. 371-383.

CAudill, M.R., AND Driese, S.G., 1996, Burial diagenesis in vertic paleosols: physical compaction and implications for paleo-precipitation estimates (abstract): Geological Society of America, Annual Meeting, Abstracts, v. 28(7), p. A472.

Chatterjee, S., Borns, H.W., And Hotton, N., 1983, Gondwana rocks of the Allan Hills: U.S. Antarctic Journal, v. 78 (5), p. 21-24.

CHEN, P.-Y., 1977, Table of key lines in X-ray powder diffraction patterns of minerals in clays and associated rocks: Indiana Geological Survey, Occasional Paper 21, 67 p.

Ciolkosz, E.J., Peterson, G.W., Cunningham, R.L., and Matelski, R.P., 1979, Soils developed from colluvium in the Ridge and Valley area of Pennsylvania: Soil Science, v. 128, p. 153162.

Ciolkosz, E.J., Waltman, W.J., Simpson, T.W., and Dobos, R.R., 1989, Distribution and genesis of soils of the northeastern United States: Geomorphology, v. 2, p. 285-302.

CoAtes, D.A., Stricker, G.D., AND LANDis, E.R., 1990, Coal geology, coal quality, and coal resources in Permian rocks of the Beacon Supergroup, Transantarctic Mountains, Antarctica, in Spletstoesser, J.F., and Dreschoff, G.A.M., eds., Mineral Resources Potential of Antarctica: American Geophysical Union, Antarctic Research Series, v. 51, p. 133-162.

Collinson, J.W., 1990, Depositional setting of Late Carboniferous to Triassic biota in the Transantarctic Basin, in Taylor, T.N., and Taylor, E.L., eds., Antarctic Paleobiology: New York, Springer-Verlag, p. 1-13.

Collinson, J.W., Isbell, J.L., Elliot, D.H., Miller, M.F., and Miller, J.M.G., 1994, PermianTriassic Transantarctic Basin, in Veevers, J.J., and Powell, C. Mc.A., eds., Permian-Triassic Pangean Basins and Foldbelts along the Panthalassan Margin of Gondwanaland: Geological Society of America, Memoir 184, p. 173-222.

Collinson, J.W., Pennington, D.C., And Kemp, N.R., 1983, Sedimentary petrology of PermianTriassic fluvial rocks in the Allan Hills, central Victoria Land: U.S. Antarctic Journal, v. 18 , p. $20-22$.

Creber, C.T., 1990, The South Polar forest ecosystem, in Taylor, T.N., and Taylor, E.L., eds., Antarctic Paleobiology: New York, Springer-Verlag, p. 37-41.

Eberl, D.D., Srodon, J., Kralik, M., Taylor, B.E., and Peterman, Z.E., 1990, Ostwald ripening of clays and metamorphic minerals: Science, v. 248, p. 474-477.

FAO (Food and Agriculture Organization), 1975, Soil Map of the World. vol. I, Legend: Paris, UNESCO, $59 \mathrm{p}$

FAO (Food and Agriculture Organization), 1978a, Soil Map of the World. vol. VIII, North and Central Asia: Paris, UNESCO, 165 p.

FAO (Food and Agriculture Organization), 1978b, Soil Map of the World. vol. X, Australasia: Paris, UNESCO, $221 \mathrm{p}$.

FAO (Food and Agriculture Organization), 1981, Soil Map of the World. vol. V, Europe: Paris, UNESCO, 199 p.

Fawcett, P.J., Barron, E.J., Robison, V.D., and Katz, B.J., 1994, The climatic evolution of India and Australia from the Late Permian to mid-Jurassic: a comparison of climate model results with the geologic record, in Klein, G.D., ed., Pangea: Paleoclimate, Tectonics, and Sedimentation during Accretion, Zenith, and Breakup of a Supercontinent: Geological Society of America, Special Paper 288, p. 139-157.

Flores-Roman, D., Alcala-Martinez, J.R., GonZalez-Velazquez, C., and Cama-Castro, J.E., 1992, Suelos con fragipán de origen volcánico en clima semicálido y subhumedo-el caso del noreste del Estado de Moreles, México: Universidad Nacional Autonoma de México, Instituto de Geología, Revista, v. 10(2), p. 151-163. 
Folk, R., and Pittman, S., 1971, Length-slow chalcedony: a new testament for vanished evaporites: Journal of Sedimentary Petrology, v. 41, p. 1045-1058.

FREY, M., 1987, Very low grade metamorphism of clastic sedimentary rocks, in Frey, M., Low Temperature Metamorphism: Glasgow, Blackie, p. 9-58.

Gabites, H.I., 1985, Triassic paleoecology of the Lashly Formation, Transantarctic Mountains, Antarctica [unpublished MSc thesis]: Victoria University of Wellington, $141 \mathrm{p}$

Hall, G.F., Daniels, R.B., And Foss, J.E., 1982, Rate of soil formation and renewal in the U.S.A, in Schmidt, B.L., ed., Determinants of Soil Loss Tolerance: American Society of Agronomy, Special Publication 45, p. 23-39.

Hammer, W.R., 1990, Triassic terrestrial vertebrate faunas of Antarctica, in Taylor, T.N., and Taylor, E.L., eds., Antarctic Paleobiology: New York, Springer-Verlag, p. 42-50.

Hammer, W.R., Collinson, J.W., and Ryan, W.J., 1990, A new Triassic vertebrate fauna from Antarctica and its depositional setting: Antarctic Science, v. 2, p. 163-167.

Hammer, W.R., AND Zawiskie, J.M., 1982, Beacon fossils from northern Victoria Land: U.S Antarctic Journal, v. 17, p. 13-15.

Heer, O., 1868, Die fossile Flora der Polarländer enthaltend die in Nordgrönland, auf der Melville-Insel, im Banksland, am Mackenzie, in Island und in Spetzbergen entdecken fossilen Pflanzen: Flora Fossilis Arcticis, Zurich, v. 1, 192 p.

Horner, T.C., and KrisseK, L.A., 1991, Permian and Triassic paleosols from the Beardmore Glacier region, Antarctica: U.S. Antarctic Journal, v. 26, p. 7-8.

Holzhey, C.S., Yeck, R.D., and NetTleton, W.D., 1974, Microfabric of some argillic horizons in udic, xeric and torric soil environments of the United States, in Rutherford, G.K., ed., Soil Microscopy: Kingston, Ontario, Limestone Press, p. 747-760.

Isbell, R.F., 1993, A classification system for Australian soils: Commonwealth Scientific and Industrial Research Organization (CSIRO), Division of Soils, Technical Report 2/1993, 92 p.

JENIK, J., 1978, Roots and root systems in tropical trees: morphologic and ecological aspects, in Tomlinson, P.B., and Zimmerman, M.H., eds., Tropical Trees as Living Systems: Cambridge, U.K., Cambridge University Press, p. 323-349.

Jensen, A.R., 1975, Permo-Triassic stratigraphy and sedimentation in the Bowen Basin, Queensland: Australia, Bureau of Mineral Resources, Bulletin 154, 187 p.

KorSCH, J.J., 1984, Petrographic comparison of the Taylor and Victoria Groups (Devonian and Triassic) in South Victoria Land, Antarctica: New Zealand Journal of Geology and Geophysics, v. 17, p. 523-541.

Krishna, P.C., AND Perumal, S., 1948, Structure in black cotton soils of the Nizamsagar Project area, Hyderabad state, India: Soil Science, v. 66, p. 29-38.

KRull, E.S., and Retallack, G.J., 1995, Clastic dikes as evidence for discontinuous permafrost paleoclimate in Permian coal measures, Allan Hills, Antarctica (abstract): Geological Society of America, Abstracts, v. 27(8), p. A265.

KutZBach, J., 1994, Idealized Pangean climates: sensitivity to orbital change, in Klein, G.deV., ed., Pangea: Paleoclimate, Tectonics, and Sedimentation during Accretion, Zenith, and Breakup of a Supercontinent: Geological Society of America, Special Paper 288, p. 41-55.

KutZBach, J., and Gallimore, R.G., 1989, Pangean climates: megamonsoons of the megacontinent: Journal of Geophysical Research, v. 94, p. 3341-3357.

Kyle, R.A., 1977, Palynostratigraphy of the Victoria Group of South Victoria Land, Antarctica: New Zealand Journal of Geology and Geophysics, v. 20, p. 1081-1102.

Kyle, R.A., And Schopf, J.M., 1982, Permian and Triassic stratigraphy of the Victoria Group, Transantarctic Mountains, in Craddock, C., ed., Antarctic Geoscience: Madison, Wisconsin, University of Wisconsin Press, p. 649-659.

Lindbo, D.L., and Veneman, P.L.M., 1989, Fragipans in the northeastern United States, in Smeck, N.E., and Ciolkosc, E.J., eds., Fragipans: Their Occurrence, Classification, and Genesis: Soil Science Society of America, Special Publication 24, p. 11-31.

MACFAYDEN, W.A., 1950, Sandy gypsum crystals from Berbera, British Somaliland: Geologica Magazine, v. 87, p. 409-420.

Maglione, G., 1981, An example of recent continental sedimentation: the Chadian Basin (Africa), in Busson, G., ed., Evaporite Deposits: Houston, Texas, Gulf Oil Co., p. 5-9.

Marbut, C.F., 1935, Atlas of American agriculture. Part III. Soils of the United States: Washington D.C., U.S. Government Printing Office, 98 p.

MARKwick, P., 1994, "Equability", continentality, and Tertiary "climate": the crocodilian perspective: Geology, v. 22, p. 613-616.

Matthews, S.D., 1983, Soil Survey of Jefferson Parish, Louisiana: U.S. Soil Conservation Service, Soil Survey, v. 24, 15 p.

Matthews, S.D., 1984, Soil Survey of Lafourche Parish, Louisiana: U.S. Soil Conservation Service, Soil Survey, v. 25, 106 p.

McCahon, T.J., and Miller, K.B., 1996, Climatic significance of natric horizons in Permian (Asselian) paleosols of north central Kansas, U.S.A.: Sedimentology, v. 43. p. 113-125.

Meyer, R., 1983, Fixacion de la silice dans les environnements continenteaux: Centres Recherche Exploration-Production Elf Aquitaine, Bulletin, v. 8, p. 195-207.

Meyer-Berthaud, B., Taylor, E.L., and Taylor, T.N., 1992, Reconstructing the Gondwana seed fern Dicroidium: evidence from the Triassic of Antarctica: Geobios, v. 25, p. 341-344.

Meyer-Berthaud, B., Taylor, T.N., and Taylor, E.L., 1993, Petrified stems bearing Dicroidium leaves from the Triassic of Antarctica: Palaeontology, v. 36, p. 337-356.

Morante, R., 1996, Permian and Triassic isotopic records of carbon and strontium in Australia and a scenario of events about the Permian-Triassic boundary: Historical Biology, v. 11, p $289-310$.

Morante, R., Veevers, J.J., Andrew, A.S., and Hamilton, P.J., 1994, Determination of the Permian-Triassic boundary in Australia from carbon isotope stratigraphy: Australian Petroleum Exploration Association, Journal, v. 34, p. 330-336.

MurPhy, C.P., 1983, Point-counting pores and illuvial clay in thin section: Geoderma, v. 31, p. $133-150$.

Nettleton, W.D., McCracken, R.J., and Daniels, R.B., 1968, Two North Carolina coastal plain catenas. II. Micromorphology, composition, and fragipan genesis: Soil Science Society of America, Proceedings, v. 32, p. 582-587.
NickEL, E.H., AND Nichols, M.C., 1991, Mineral Reference Manual: New York, Van Nostrand, $250 \mathrm{p}$.

Northсоте, K.H., 1974, A Factual Key for the Recognition of Australian Soils: Adelaide, Rellim, 123 p.

Paton, T.R., 1974, Origin and terminology for gilgai in Australia: Geoderma, v. 11, p. 221242.

Pyne, A.R., 1984, Geology of the Mt Fleming area, south Victoria Land, Antarctica: New Zealand Journal of Geology and Geophysics, v. 27, p. 505-512.

Ready, C.D., and Retallack, G.J., 1995, Chemical composition as a guide to paleoclimate of paleosols (abstract): Geological Society of America, Abstracts, v. 27, p. A237.

Retallack, G.J., 1977a, Triassic palaeosols of the upper Narrabeen Group of New South Wales. Part 1. Features of the palaeosols: Geological Society of Australia, Journal, v. 23 p. $383-397$

Retallack, G.J., 1977b, Triassic palaeosols in the upper Narrabeen Group of New South Wales. Part II. Classification and reconstruction: Geological Society of Australia, Journal, v. 24 , p. $19-35$.

Retallack, G.J., 1977c, Reconstructing Triassic vegetation of eastern Australasia: a new approach for the biostratigraphy of Gondwanaland: Alcheringa, v. 1, p. 247-277.

Retallack, G.J., 1978, Floral ecostratigraphy in practice: Lethaia, v. 11, p. 81-83.

Retallack, G.J., 1981, Middle Triassic megafossil plants from Long Gully, near Otematata, North Otago, New Zealand: Royal Society of New Zealand, Journal, v. 11, p. 167-200.

Retallack, G.J., 1987, Triassic vegetation and geography of the New Zealand portion of the Gondwana supercontinent, in McKenzie, G.D., ed., Gondwana Six: Stratigraphy and Paleontology: American Geophysical Union, Geophysical Monograph 41, p. 29-39.

Retallack, G.J., 1988, Field recognition of paleosols, in Reinhardt, J., and Sigleo, W.R., eds., Paleosols and Weathering through Geologic Time: Principles and Applications: Geological Society of America, Special Paper 216, p. 1-20.

Retallack, G.J., 1990, Soils of the Past: London, Unwin-Hyman, 521 p.

Retallack, G.J., 1991a, Miocene Paleosols and Ape Habitats in Pakistan and Kenya: New York, Oxford University Press, $246 \mathrm{p}$.

RETALLACK, G.J., 1991b, Untangling the effects of burial alteration and ancient soil formation: Annual Review of Earth and Planetary Sciences, v. 19, p. 183-206.

Retallack, G.J., 1994, A pedotype approach to latest Cretaceous and earliest Tertiary paleosols in eastern Montana: Geological Society of America, Bulletin, v. 106, p. 1377-1397.

Retallack, G.J., 1995, Permian-Triassic extinction on land: Science, v. 267, p. 77-80.

Retallack, G.J., 1997a, Palaeosols in the upper Narrabeen Group of New South Wales as evidence of Early Triassic paleoenvironments without modern analogue: Australian Journal of Earth Sciences, v. 44, p. 185-201.

Retallack, G.J., 1997b, Post-apocalyptic greenhouse paleoclimate revealed by earliest Triassic paleosols of the Sydney Basin, Australia: Geological Society of America, Bulletin, in press

Retallack, G.J., and Dilcher, D.L., 1988, Reconstructions of selected seed ferns: Missourt Botanical Garden, Annals, v. 75, p. 1010-1057.

Retallack, G.J., Krull, E.S., and Robinson, S.E., 1997a, Permian and Triassic paleosols and paleoenvironments of southern Victoria Land, Antarctica: U.S. Antarctic Journal, in press. Retallack, G.J., Krull, E.S., and Robinson, S.E., 1997b, Permian and Triassic paleosols and paleoenvironments of the central Transantarctic Mountains, Antarctica: U.S. Antarctic Journal, in press.

Retallack, G.J., Renne, P.R., and Kimbrough, D.L., 1993, New radiometric ages for Triassic floras of southeast Gondwana, in Lucas, S.G., and Morales, P., eds., The Non-Marine Triassic: New Mexico Museum of Natural History and Science, Bulletin, v. 3, p. 415-418.

Retallack, G.J., Veevers, J.J., and Morante, R., 1996, Global coal gap between PermianTriassic extinction and Middle Triassic recovery of peat-forming plants: Geological Society of America, Bulletin, v. 108, p. 195-207.

Sclater, J.G., AND Christie, J.A.F., 1980, Continental stretching: an explanation of the postmid-Cretaceous subsidence of the North Sea Basin: Journal of Geophysical Research, v. 85, p. 3711-3739.

SCOTESE, C.R., 1994, Early and Late Triassic palaeogeographic maps, in Klein, G. deV., ed., Pangea: Paleoclimate, Tectonics, and Sedimentation during Accretion, Zenith, and Breakup of a Supercontinent: Geological Society of America, Special Paper 288, p. 7.

SEWARD, A.C., 1914, Antarctic fossil plants: Natural History Reports in Geology of the British Antarctic Expedition (Terra Nova), v. 1, p. 1-49.

Slingo, A., And Slingo, J., 1991, Response of the National Center for Atmospheric Research Community Climate Model to improvements in the representation of clouds: Journal of Geophysical Research, v. 96, p. 15,341-15,357.

SмYтн, M., 1980, Coal encounters of the third kind: Triassic: Australian Coal Geology, v. 2, p. $161-177$.

Soll Survey Staff, 1975, Soil Taxonomy: U.S. Department of Agriculture, Handbook 436, $754 \mathrm{p}$.

Soll Survey Staff, 1990, Keys to Soil Taxonomy: Soil Management Support Services, Blacksburg, Virginia, Technical Monograph 19, 422 p.

Stace, H.C.T., Hubble, G.D., Brewer, R., Northcote, K.H., Sleeman, J.R., Mulcahy, M.J., and Hallsworth, E.G., 1968, A Handbook of Australian Soils: Adelaide, Rellim, 435 p.

Steele, F., Daniels, R.B., Gamble, E.E., and Nelson, L.A., 1969, Fragipan horizons and Be masses in the middle Coastal Plain of north central North Carolina: Soil Science Society of America, Proceedings, v. 33, p. 752-755.

TAYLOR, E.L., AND TAYLOR, T.N., 1988, Late Triassic flora from Mount Falla, Queen Alexandra Range: U.S. Antarctic Journal, v. 23(5), p. 2-3.

TAYLOR, E.L., AND TAYLOR, T.N., 1993, Fossil tree rings and paleoclimate from the Triassic of Antarctica, in Lucas, S.G., and Morales, M., eds., The Non-Marine Triassic: New Mexico Museum of Natural History and Science, Bulletin 3, p. 453-455.

TAYLOR, E.L., TAYLOR, T.N., AND Collinson, J.W., 1989, Depositional setting and paleobotany 
of Permian and Triassic permineralized peat from the central Transantarctic Mountains, Antarctica: International Journal of Coal Geology, v. 12, p. 657-679.

Taylor, E.L., Taylor, T.N., AND CunEO, N.R., 1992, The present is not the key to the past: a polar forest from the Permian of Antarctica: Science, v. 257, p. 1675-1677.

Taylor, E.L., TAylor, T.N., Meyer-Berthaud, B., and Isbell, J.L., 1990, A late Triassic flora from the Allan Hills, southern Victoria Land: U.S. Antarctic Journal, v. 25, p. 20-21.

Taylor, T.N., Taylor, E.L., and Del Fueyo, G., 1993, Permineralized Triassic plants from Antarctica, in Lucas, S.G., and Morales, M., eds., The Non-Marine Triassic: New Mexico Museum of Natural History and Science, Bulletin 3, p. 457-460.

Taylor, T.N., TAylor, E.L., Meyer-Berthaud, B., Isbell, J.L., and Cuneo, N.R., 1990, Triassic osmundaceous ferns from the Allan Hills, southern Victoria Land: U.S. Antarctic Journal, v. 25, p. $18-19$.

Townrow, J.A., 1967, Fossil plants from Allan and Carapace Nunataks and from the upper Mill and Shackleton Glaciers, Antarctica: New Zealand Journal of Geology and Geophysics, v. 10 , p. $456-473$.

VeEvers, J.J., 1989, Middle/Late Triassic $(230 \pm 5 \mathrm{Ma})$ singularity in the stratigraphic and magnetic history of the Pangean heat anomaly: Geology, v. 17, p. 784-787.

Veevers, J.J., Powell, C.McA., Collinson, J.W., and Lopez-Gamundi, O.R., 1994, Synthesis, in Veevers, J.J., and Powell, C.McA., eds., Permian-Triassic Pangean Basins and Foldbelts along the Panthalassan Margin of Gondwanaland: Geological Society of America, Memoir 184 , p. 331-353.

Walter, H., Harnickell, E., And Mueller-Dombois, D., 1975, Climate-Diagram Maps of the
Individual Continents and the Ecological Climatic Regions of the Earth: Berlin, SpringerVerlag, $26 \mathrm{p}$

WeAver, J.E., 1919, The ecological relations of roots: Carnegie Institute of Washington, Publication $286,128 \mathrm{p}$.

Williams, G.E., 1986, Precambrian permafrost horizons as indicators of palaeoclimate: Precambrian Research, v. 32 , p. 233-242.

Wilson, K.M., Pollard, D., Hay, W.W., Thompson, S.L., and Wold, C.N., 1994, General circulation model simulations of Triassic climates: preliminary results, in Klein, G.deV., ed., Pangea: Paleoclimate, Tectonics, and Sedimentation during Accretion, Zenith, and Breakup of a Supercontinent: Geological Society of America, Special Paper 288, p. 91-116.

Woolfe, K.J., Arnot, M.J., Barrett, P.J., And Francis, J.E., 1996, Geology of the Allan Hills, southern Victoria Land, Antarctica-with special reference to the Beacon Supergroup: New Zealand Journal of Geology and Geophysics, in press.

Yemane, K., 1993, Contribution of a Late Permian palaeogeography in maintaining a temperate climate in Gondwana: Nature, v. 361, p. 51-54.

Ziegler, A.M., Parrish, J.M., Yao, J.-P. Gyllenhad, E.C., Rowley, D.B., Parrish, J.T., Nie, S.-Y., BekKer, A., AND Hulver, M.L., 1993, Early Mesozoic phytogeography and climate: Royal Society [London], Philosophical Transactions, v. B341, p. 297-305.

Zwartz, D.P., AND Woolfe, K.J., 1996, Superimposed litho- and pedo-facies in a fluviallacustrine sequence: Sedimentary Geology, in press.

Received 24 June 1996; accepted 17 April 1997. 